\title{
Calcium Signaling in Interstitial Cells: Focus on Telocytes
}

\author{
Beatrice Mihaela Radu 1,2, ${ }^{\dagger}$, Adela Banciu $2,3,4,+$, Daniel Dumitru Banciu 2,3 , Mihai Radu ${ }^{1,5}$, \\ Dragos Cretoiu ${ }^{6,7}$ and Sanda Maria Cretoiu 6,7,*
}

1 Department of Neuroscience, Biomedicine and Movement Sciences, University of Verona, Strada Le Grazie 8, Verona 37134, Italy; beatrice.mihaela.radu@gmail.com (B.M.R.); mradu@nipne.ro (M.R.)

2 Department of Anatomy, Animal Physiology and Biophysics, Faculty of Biology, University of Bucharest, Splaiul Independentei 91-95, Bucharest 050095, Romania; adela.banciu79@gmail.com (A.B.);

danieldumitrubanciu@gmail.com (D.D.B.)

3 Research Beyond Limits, Dimitrie Cantemir 15, Bucharest 040234, Romania

4 Engineering Faculty, Constantin Brancusi University, Calea Eroilor 30, Targu Jiu 210135, Romania

5 Department of Life and Environmental Physics, Horia Hulubei National Institute of Physics and

Nuclear Engineering, Reactorului 30, P.O. Box MG-6, Magurele 077125, Romania

6 Division of Cell Biology and Histology, Carol Davila University of Medicine and Pharmacy,

Bucharest 050474, Romania; dragos@cretoiu.ro

7 Victor Babes National Institute of Pathology, Bucharest 050096, Romania

* Correspondence: sanda@cretoiu.ro; Tel.: +40-724-319-277

+ These authors contributed equally to this work.

Academic Editor: ChulHee Kang

Received: 4 October 2016; Accepted: 25 January 2017; Published: 13 February 2017

\begin{abstract}
In this review, we describe the current knowledge on calcium signaling pathways in interstitial cells with a special focus on interstitial cells of Cajal (ICCs), interstitial Cajal-like cells (ICLCs), and telocytes. In detail, we present the generation of $\mathrm{Ca}^{2+}$ oscillations, the inositol triphosphate $\left(\mathrm{IP}_{3}\right) / \mathrm{Ca}^{2+}$ signaling pathway and modulation exerted by cytokines and vasoactive agents on calcium signaling in interstitial cells. We discuss the physiology and alterations of calcium signaling in interstitial cells, and in particular in telocytes. We describe the physiological contribution of calcium signaling in interstitial cells to the pacemaking activity (e.g., intestinal, urinary, uterine or vascular pacemaking activity) and to the reproductive function. We also present the pathological contribution of calcium signaling in interstitial cells to the aortic valve calcification or intestinal inflammation. Moreover, we summarize the current knowledge of the role played by calcium signaling in telocytes in the uterine, cardiac and urinary physiology, and also in various pathologies, including immune response, uterine and cardiac pathologies.
\end{abstract}

Keywords: interstitial cells; telocytes; calcium signaling; $\mathrm{Ca}^{2+}$ oscillations; pacemaker activity

\section{Introduction}

\subsection{Definition and Nomenclature for Interstitial Cells}

Interstitial cells are defined as cells pertaining to or situated between parts or in the interspaces of a tissue. These cells are located in the connective tissue and under the umbrella of this terminology we find reunited cells such as the interstitial cells of Cajal (ICCs), the testosterone-secreting cells of the testis (Leydig cells), the cells in the medulla and cortex of the kidney, the cells found in the connective tissue of the ovary, the aortic valve interstitial cells, etc. [1-4]. As one can perceive, all these cells differ as to origin and phenotype. Moreover, histologists consider that the usually described cells of the connective tissue might also be viewed as interstitial cells, e.g., fibroblasts, mast cells, macrophages and 
blood-derived immune cells (plasma cells, neutrophils, eosinophils, and lymphocytes). From the point of view of pathologists, all cells expressing vimentin can be identified as interstitial cells [5]. This review describes calcium signaling in interstitial cells with a special focus on ICCs in the gastrointestinal tract, on interstitial Cajal-like cells (ICLCs) in the extra-digestive organs and on telocytes (TCs), a novel type of interstitial cells. Several other interstitial types are reached in our discussion because the signaling through calcium oscillations is significant in their case although these cells differ in origin.

\subsection{Interstitial Cells of Cajal (ICCs)}

ICCs were described in 1892, by the Spanish neuroanatomist, histologist and pathologist, Santiago Ramon y Cajal, as primitive neurons in the intestinal wall [6]. There are many attempts to classify the ICCs as different subtypes, most of them based on their location in various organs of the digestive tract wall [7]. During the twentieth century, ICCs were described morphologically in the gastrointestinal tract as frequently forming networks around the myenteric plexus (Auerbach's plexus) and along the whole digestive tube in the submucosa, in the connective tissue septa of the muscularis and in the subserosa. These classifications are not subject to this review.

\subsubsection{Ultrastructural Features of ICCs}

In the mid-1970s, the ultrastructural features of ICCs were described for the first time by an Italian electron-microscopist Faussone-Pellegrini, who also resumed the first functional hypothesis postulated by Tiegs regarding the role of ICCs in triggering, propagating and coordinating the rhythmic intestinal contractile activity [8]. Since the publishing of the first guide to the identification of ICCs, it was emphasized that these cells might be classified in species- and location-dependent types [9]. ICCs are characterized by small cell bodies and several narrow, rounded, or only slightly flattened cytoplasmic extensions. The ultrastructural criteria for ICCs' differential and positive diagnosis include: (a) the presence of a discontinuous basal lamina; (b) numerous plasmalemmal caveolae; (c) numerous mitochondria and abundant intermediate filaments, moderately developed Golgi apparatus, and rough and smooth endoplasmic reticulum cisternae and tubules in the cytoplasm; and (d) close contacts established with nerve endings and the realization of numerous gap junctions, both with each other, and with smooth muscle in the muscularis of the enteric wall [10].

\subsubsection{Immunophenotype of ICCs}

Today, in the "omics" era, electron microscopy remains the only reliable method of identification of ICCs. Different histological techniques, starting with the ones described by Cajal himself, were shown to have their limitations in ICCs identification [11]. This fact represented a challenge for immunohistochemistry which still struggles to identify an appropriate marker for the identification of interstitial cells. In the early 2000s, antibodies to c-Kit were considered as useful to the identification of ICCs $[12,13]$ even more as the lack of expression of proto-oncogene c-kit appeared to be closely correlated with the loss of mechanical rhythmicity of the gut [14,15]. In the late 2000s, Ano1, a $\mathrm{Ca}^{2+}$-activated $\mathrm{Cl}^{-}$channel, was demonstrated to be a highly specific marker for studying the distribution of ICCs in the gastrointestinal tract, being able to label all classes of ICCs $[16,17]$.

\subsubsection{Roles of ICCs}

The acknowledged physiological roles of ICCs are: (a) to provide pacemaker activity in the gastrointestinal smooth muscles; and (b) to act as transducers of inputs from motor neurons, and stretch receptors [18]. These functions are $\mathrm{Ca}^{2+}$ dependent [19] since the release of $\mathrm{Ca}^{2+}$ from internal stores activates $\mathrm{Ca}^{2+}$-dependent $\mathrm{Cl}^{-}$channels and participates in the regenerative potentials $[20,21]$. 


\subsection{Interstitial Cajal-Like Cells (ICLCS)}

The mid-2000s were marked by the discovery of c-kit positive cells in organs capable of peristaltic movements, e.g., the upper urinary tract, bladder, and vas deferens [22-24]. Their role was discussed extensively in reviews at that time and it still is nowadays [25-28]. Gradually, such cells were described in several extra-digestive organs: uterus, fallopian tube, vagina, pancreas, prostate, mammary gland and blood vessels [29-35]. These cells, which resemble, by ultrastructural appearance, the canonical ICCs, were found at that time under different names: ICC-like cells, interstitial Cajal-like cells (ICLC), platelet-derived growth factor receptor alpha (PDGFR $\alpha$ ) positive cells, etc. In their attempt to characterize these cells, researchers found that the interstitial cells located in the above-mentioned organs might express different immunophenotypes depending on their location in organs and on species [36,37]. In fact, while some of these cells might share morphological, immunophenotypical and functional similarities with ICCs, others share the same characteristics with TCs [38]. In a set of reports, Vannucchi and collaborators $[1,38,39]$ solved the controversy regarding the existence of a different population of interstitial Cajal-like cells in the gut. These cells, expressing cluster of differentiation 34 (CD34) and PDGFR $\alpha$ in the gut, were shown to be involved in regulating motility by interaction with ICCs [39]. As shown in Figure 1, authors demonstrated that all cells expressing CD34 are also positive for PDGFR $\alpha$, and therefore these cells could not be interpreted as ICCs which are diagnosed by their c-kit immunophenotype. At present, there is still controversy regarding the various classes of interstitial cells, however, the presence of PDGFR $\alpha$ positive cells in the gut is admitted by many groups as reviewed by Sanders et al. [40].

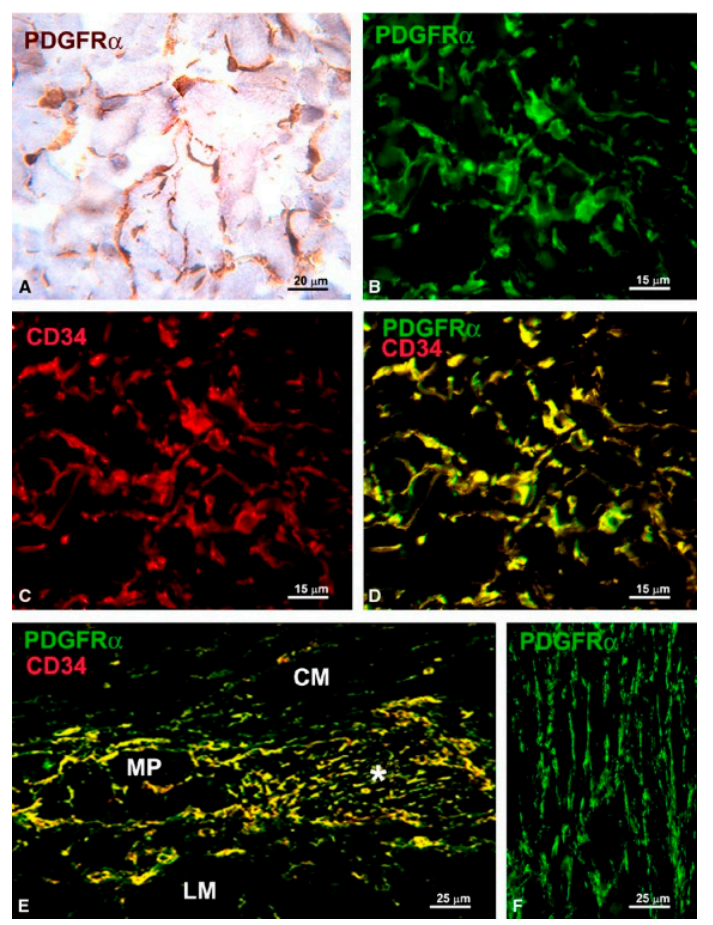

Figure 1. (A,B,F) PDGFR $\alpha$-immunoreactivity; (C) CD34-immunoreactivity; and (D,E) PDGFR $\alpha / C D 34$ double labeling. (A) Immunohistochemistry, hematoxylin counterstain; (B-F) Immunofluorescence. (A-D) Submucosa (stomach). PDGFR $\alpha$-positive cells (A,B) and CD34-positive cells (C) form a 3-D network. All the PDGFR $\alpha$-positive cells are also CD34-positive (D). (E) Myenteric plexus region (large intestine). PDGFR $\alpha$ /CD34-positive cells surround a ganglion (left side, MP) and form networks in the intergangliar region (right side, asterisk). (F) Circular muscle layer (small intestine). PDGFR $\alpha$-positive cells form networks among the smooth muscle cells. CM: circular muscle layer; LM: longitudinal muscle layer. Scale bars are indicated in each panel. Reproduced from [39], published under the Creative Commons license. 


\subsection{TCS}

\subsubsection{Discovery, Definition and Ultrastructural Features}

TCs were described as a new type of interstitial (stromal) cells in 2010 by Popescu's team. They had started to search for ICCs in the extra-digestive organs and stopped when they realized that what they observed was, in fact, a distinct cell type [41]. TCs are shortly defined as cells with telopodes. Telopodes is the name used to describe the extremely long (tens to hundreds of micrometers) and thin (between 0.05 and 0.2 micrometers) cytoplasmic extensions emitted from the cell body [42]. In addition, telopodes are made up of a succession of thin, fibrillar segments called podomers ( 75-80 nm) and the dilated, cistern-like regions called podoms $(250-300 \mathrm{~nm})[43,44]$. Podoms accommodate functional units consisting of caveolae, mitochondria, and endoplasmic reticulum, possibly involved in calcium uptake/release [45]. Cytoplasmic organelles are limited, e.g., mitochondria 5\%, endoplasmic reticulum $1 \%-2 \%$, and caveolae $2 \%-3 \%$ of cell volume [41]. TCs are able to release extracellular vesicles and therefore are considered as important players in intercellular communication (for review see [46]). Telopodes are building up a 3D network by interacting with each other by homocellular junctions [45]. In addition, TCs contact, by their telopodes, numerous surrounding cells or structures. Figure 2 is relevant for such heterocellular contacts between a TC and some immune cells [44].
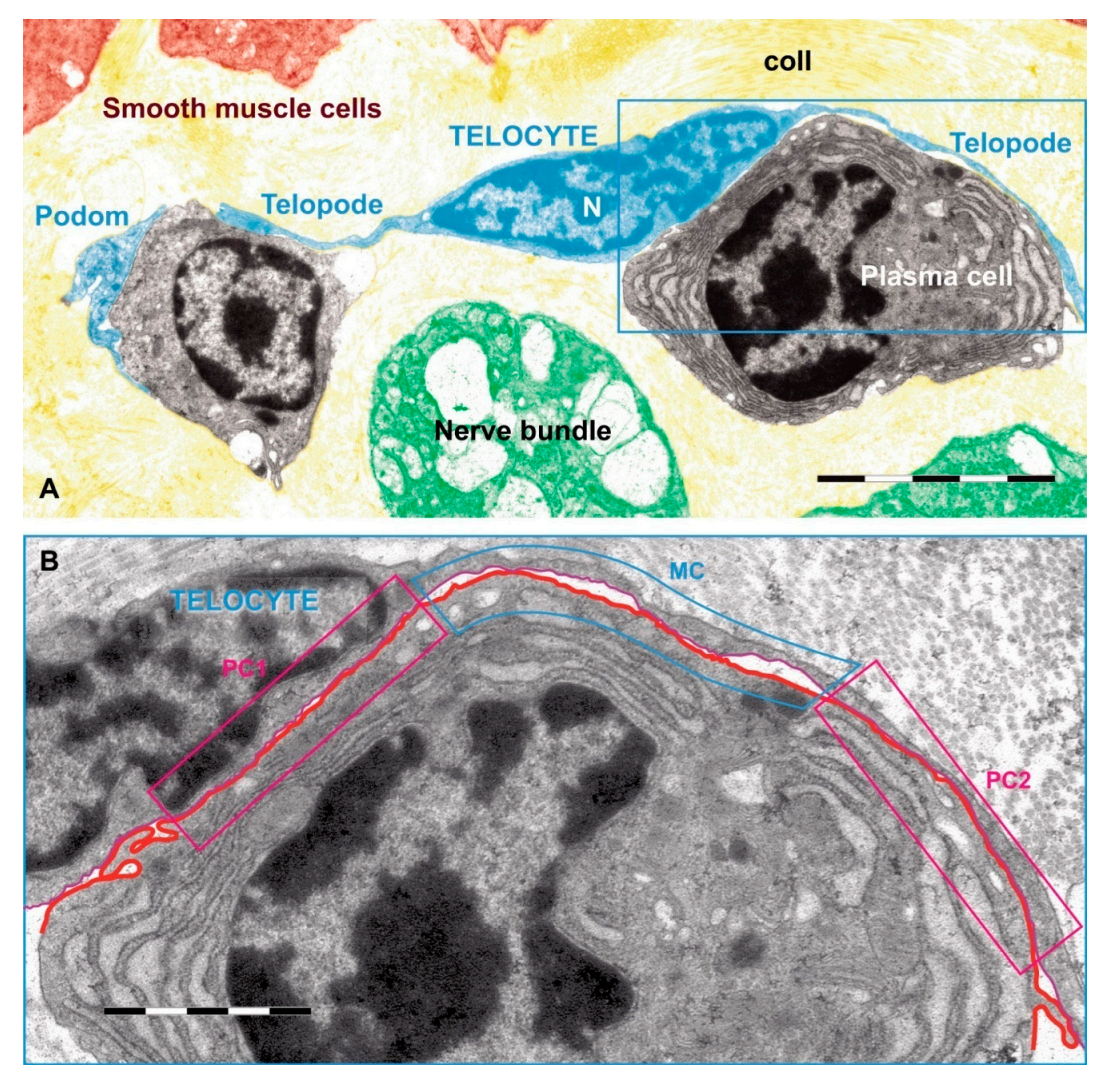

Figure 2. Rat jejunum mucosa: (A) A telocyte (blue) telopode is engaged in different types of synapses with a plasma cell, and two plain synapses (PC1 and PC2) and one multicontact synapse (MC) are seen; (B) region magnified from (A). Scale bar: (A): $5 \mu \mathrm{m},(B): 2 \mu \mathrm{m}$. Reproduced with permission from [44].

There is a growing body of evidence highlighting that TCs are different from ICCs, fibroblasts (as shown in Figure 3) and mesenchymal stem cells, not only by morphology [44] but also by their genomic and proteomic characteristics [47]. 

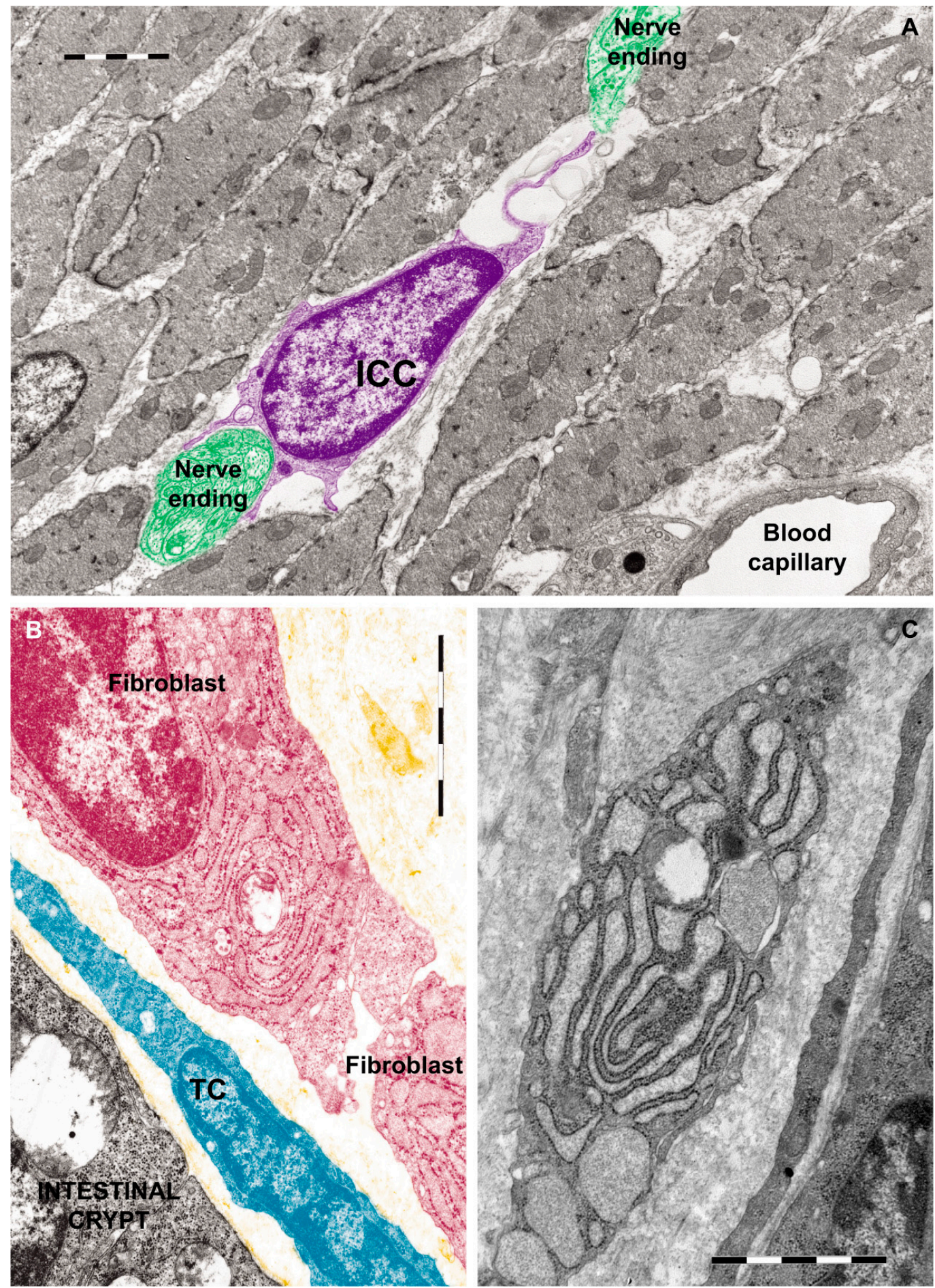

Figure 3. Rat jejunum: (A) Photomicrograph of an interstitial cell of Cajal (violet) in muscularis externa. Note the large cell body which extends a slender and relatively short connection towards the nerve endings (green); (B) Digitally colored TEM image showing a fibroblast (garnet) and a telocyte (blue) in the lamina propria; (C) Transmission electron micrograph (TEM) of a tangential section through a fibroblast cell. The internal structure can be seen, including the dilated rough endoplasmic reticulum responsible for synthesizing collagen. Reproduced with permission from [44]. 


\subsubsection{Immunophenotype of TCs}

Several experiments performed by many research groups in their attempt to find a specific immunohistochemical marker illustrate that the most appropriate way to differentiate between TCs and other interstitial cells is the double-positive immunostaining with CD34/PDGFR ( $\alpha$ or $\beta)$. Additionally, TCs positive for the alpha smooth muscle antibody ( $\alpha \mathrm{SMA})$ or for calreticulin antibody (calret) have also beenconsidered in this classification. Thus, in his articles Vannucchi and collaborators $[1,38,39]$ describe in the bladder, three subtypes of TCs: the first subtype located beneath urothelium was PDGFR $\alpha /$ calret-positive and $\alpha \mathrm{SMA} / \mathrm{CD} 34 / \mathrm{c}-\mathrm{Kit}$-negative; the second subtype in the deep suburothelium is PDGFR $\alpha /$ calret/ $\alpha$ SMA-positive and CD34/c-Kit-negative; and a third TC subtype, PDGFR $\alpha / \alpha \mathrm{SMA} / \mathrm{c}-\mathrm{Kit}$-negative and CD34/calret-positive, is in the submucosa and detrusor. Díaz-Flores et al. emitted the hypothesis that TCs have progenitor capacity and are a source of $\alpha \mathrm{SMA}+$ cells during repair [37].

\subsubsection{Roles of TCs}

TCs were very well characterized during previous years regarding their genomic and proteomic profiles [48-52]. TCs are not fibroblasts or mesenchymal stem cells [53,54]. Among the most important functions of the TCs, we can mention that of integrators of many intercellular signaling processes (for details see our latest review [55]).

\section{Calcium Signaling in Interstitial Cells}

\subsection{Main Calcium Signaling Pathways in Interstitial Cells}

RT-PCR based studies proved the presence in ICCs of some specific neurotransmitter receptors assuring the functional connection of these cells to adjacent neurons. In ICCs isolated from the murine gastrointestinal tract the expression of muscarinic acetylcholine receptors $\left(\mathrm{M}_{2}\right.$ and $\left.\mathrm{M}_{3}\right)$ and of substance P receptors were evidenced [56]. In addition, the purinergic receptor P2X (P2X2 and P2X5 subtypes) has been found by immunofluorescence in the ICCs of guinea pigs intestines [57]. Among the calcium permeant membrane channels, the transient receptor potential melastin channels, particularly TRPM7, were identified in the ICCs from the human gastro-intestinal tract [58]. Moreover, the calcium oscillations are dependent on the presence of the calcium concentration outside of the ICCs from rabbit urethra [59]. These findings clearly indicate the presence in ICCs of the most common calcium signaling pathways: the IP3 path and the store operated membrane calcium channels path. Actually, the description of the mechanism of the oscillations is based on these two basic cytosolic $\mathrm{Ca}^{2+}$ control modalities.

The IP3/ $\mathrm{Ca}^{2+}$ signaling pathway was described to be involved in multiple cellular processes, including metabolism, contraction, fertilization, exocytosis, proliferation, fluid secretion, neuronal synaptic plasticity, aggregation, ion channel opening, aldosterone secretion, differentiation, proliferation, etc. $[60,61]$. The IP3/ $\mathrm{Ca}^{2+}$ oscillatory mechanism controls the rhythmic contractions of vascular, lymphatic, airway and corpus cavernosum smooth muscle cells [62], and was also proposed to be active in pacemaking cells such as ICCs $[61,63] . \mathrm{Ca}^{2+}$ signaling mechanisms in ICCs involve both ryanodine receptors (RyR) and inositol triphosphate receptors (InsP3R). The interdependence between RyR and InsP3R in the generation of $\mathrm{Ca}^{2+}$ transients, and the dominant transcripts expression of Itpr1 and Ryr2 in ICCs were demonstrated [64].

A very important aspect should be highlighted: isolated ICCs present differences in $\mathrm{Ca}^{2+}$ signaling mechanisms with respect to the cells in intact muscles. To date, it was suggested that release of $\mathrm{Ca}^{2+}$ from both $\mathrm{IP}_{3}$ and ryanodine receptors is important in generating pacemaker activity in ICCs [65].

Another important calcium signaling pathway, based on the calcium ions influx from outside of the cells, involves the presence of the plasma membrane channels permeable for calcium. As already mentioned, TRPM7 channels have been identified by immunofluorescence in human small intestine and colon and colocalized with c-KIT, proving that ICCs have this type of calcium permeant channels 
in the membrane [58]. The ability of non-specific calcium influx blockers $\mathrm{La}^{+3}$ and $\mathrm{Cd}^{2+}$ to abolish the calcium oscillations in ICCs from rabbit urethra proves the involvement of the store-operated channels path in maintaining the pacemaking activity of ICCs [59]. However, other membrane channels, such as voltage-gated calcium channels [66] and calcium-activated chloride channels including ANO1 [67], are players in the calcium oscillation generation and maintenance mechanism.

Little is known about these mechanisms in telocytes. However, the $\mathrm{T}$ and $\mathrm{L}$ subtypes voltage-gated calcium channels have been found in the telocytes from human myometrium [68].

\section{2. $\mathrm{Ca}^{2+}$ Oscillations in Interstitial Cells}

The ICCs and ICLCs are considered as electrical pacemaker cells and this role was documented for some organs like gastrointestinal tract, urinary tract and male genital organs $[63,69,70]$. It is also considered that ICLCs might intermediate the signal transduction between nervous and muscle cells [71]. These types of activity are accompanied by the generation of calcium waves of specific amplitude and frequency. The calcium signaling mechanisms involved in the generation of these waves are poorly characterized but include the basic pathways involving the release of calcium from the internal stores and the subsequent calcium operated membrane channels opening [71-76]. For some particular tissues, a model describing the $\mathrm{Ca}^{2+}$ oscillations in ICCs was proposed. It follows the general ideas of calcium waves generation in cardiac pacemaker cells using the main $\mathrm{Ca}^{2+}$ controlling paths mentioned in the previous section [77], but the model has to be verified for a larger range of ICCs, particularly for TCs.

As an important issue, these $\mathrm{Ca}^{2+}$ signals present ubiquitous temporal characteristics depending on species and tissues and have greater amplitude but lower frequency in comparison with the signals in the neighboring smooth muscle cells [70].

For the ICCs in the gastrointestinal tract a complex calcium-dependent signaling mechanism in several steps was proposed: (i) release of $\mathrm{Ca}^{2+}$ through both $\mathrm{IP}_{3}$ and ryanodine receptors in the endoplasmic reticulum membrane; (ii) activation of ANO1 channels from the plasma membrane; (iii) current flux through ANO1 channels; (iv) spontaneous transient inward currents determine the generation of spontaneous transient depolarizations; (v) the $\mathrm{Ca}^{2+}$ influx is driven through T-type voltage-dependent $\mathrm{Ca}^{2+}$ channels; (vi) the $\mathrm{Ca}^{2+}$ influx promotes further $\mathrm{Ca}^{2+}$ release through subcellular $\mathrm{IP}_{3}$ and ryanodine receptors; (vii) the enhanced release of $\mathrm{Ca}^{2+}$ from the ER synchronizes the opening of additional ANO1 channels; (viii) a slow wave current that spreads to adjacent smooth muscle cells via gap junction proteins is generated; (ix) the slow wave current causes the smooth muscle depolarization; and, finally, $(x)$ the contraction of the gastrointestinal wall is triggered $[71,78,79]$.

\subsection{Cytokines and Vasoactive agents Modulate Calcium Signaling in Interstitial Cells}

Interleukin-9 (IL-9) was shown to promote proliferation of ICCs and to enhance cholecystokinin8-induced $\mathrm{Ca}^{2+}$ transients [80]. Moreover, in murine gastric antral tissues, IL-9 receptor and cholecystokinin-1 receptor were co-localized with c-kit immunoreactivities [80]. It was also proved that IL-9 had a proliferative effect on ICCs inside tissue explants and that injured ICCs establish membrane-to-membrane contacts with mast cells in correlation with piecemeal degranulation at the ultrastructural level $[81,82]$. Additionally, mast cells were demonstrated to secrete IL-6 that modulated ICCs growth and repair [81].

Bone morphogenetic protein 2 (BMP-2) and tumor growth factor beta 1 (TGF- $\beta 1$ ) were described to be responsible for biglycan-induced pro-osteogenic reprogramming in human aortic valve interstitial cells, to upregulate the expression of osteogenic biomarkers and consequently to stimulate calcium deposition in these cells [83]. Additionally, TNF- $\alpha$ accelerated the calcification of human aortic valve interstitial cells obtained from patients with calcific aortic valve stenosis via the BMP2-Dlx5 pathway [84]. Vasoactive agents, e.g., serotonin and angiotensin II, were described to elicit maximal intracellular $\mathrm{Ca}^{2+}$ transients in cultured human valve interstitial cells [85]. 
Moreover, bradykinin was identified to modulate the pacemaker activity in cultured ICCs through bradykinin $\mathrm{B}_{2}$ receptor activation by external $\mathrm{Ca}^{2+}$ influx and internal $\mathrm{Ca}^{2+}$ release via PKC- or cyclooxygenase-independent mechanism [86]. Histamine was also shown to act on ICCs and to modulate the pacemaker activity through $\mathrm{H}_{1}$ receptor-mediated pathways via external $\mathrm{Ca}^{2+}$ influx and $\mathrm{Ca}^{2+}$ release from internal stores [87].

We may conclude that, additionally to neurotransmitters, some cytokines and vasoactive molecules are involved in controlling/mediating the ICCs function.

\section{Physiology and Alterations of Calcium Signaling in Interstitial Cells}

Calcium signaling pathways have been described in various subtypes of interstitial cells (Table 1), including ICCs, ICLCs, TCs, valve interstitial cells or Leydig cells, and the main anatomical systems have been targeted (e.g., urinary, cardiovascular, gastrointestinal, reproductive system, etc.). This exhaustive analysis revealed the contribution of the interstitial cells to the physiology and pathology of these systems. Besides the importance of calcium signaling in interstitial cells to the pacemaking activity (Figure 4), it should be emphasized that the intracellular $\mathrm{Ca}^{2+}$ fluctuations are also contributing to a wide range of physiological and pathological roles played by interstitial cells, including reproductive function, tissue remodeling, immune signaling, mechanical sensing, etc.

\subsection{Physiological Role of Calcium Signaling in Interstitial Cells}

\subsubsection{Calcium Signaling in Gastrointestinal Interstitial Cells}

The intestinal ICCs have been described to be electrically coupled to smooth muscle cells $[18,88]$ and to contribute to the pacemaking activity by affecting the resting membrane potential of the smooth muscle cells [89]. Recent studies have described the $\mathrm{Ca}^{2+}$-associated mechanisms in the intestinal ICCs that are contributing to the intestinal pacemaker activity. To date, the gastrointestinal distension (e.g., hypotonic stress) induces sustained inward holding current via actin microfilaments and the process is mediated by alteration of intracellular basal $\mathrm{Ca}^{2+}$ concentration and $\mathrm{Ca}^{2+}$ oscillations in murine cultured intestinal ICCs [90]. $\mathrm{Ca}^{2+}$ oscillations in gastrointestinal ICCs were described to depend on $\mathrm{Ca}^{2+}$ influx mediated by transient receptor potential-like channel 4 (TRP4) in caveolae [91].

Although ICCs have been generally accepted as being able to tune the luminal chemical environment, that prepares the membrane potential of smooth muscle cells (SMCs) for depolarizing or hyperpolarizing response, recent studies provide evidence for the non-contribution of ICCs to the enteric inhibitory neuromuscular neurotransmission [92].

\subsubsection{Calcium Signaling in the Interstitial Cells of the Urinary Tract}

ICCs act as pacemakers in the urinary tract [93]. ICCs were identified both in the upper and lower urinary tract, and voltage clamp recordings indicated that these cells present abundant calcium-activated chloride currents and spontaneous transient inward currents blocked by chloride channel antagonists [93]. Depending on the segment of the urinary tract, ICCs may act or not as pacemaker cells. In the urethra, ICCs have been considered as "loose pacemakers" that provide multiple and randomly modulatory inputs to the smooth muscle cells, while in the bladder or the renal pelvis, these cells are only modulators of the smooth muscle activity [94]. Other studies indicated that ICCs from the urethra are specialized pacemakers involved in the generation of urethral tone and in the maintenance of urinary continence, and there is an important contribution of intracellular $\mathrm{Ca}^{2+}$ stores and $\mathrm{Ca}^{2+}$ influx to these pacemaking mechanisms [74].

Stimuli, e.g., caffeine, muscarinic or purinergic agonists, elicit intracellular calcium concentration increases in isolated c-kit positive cells from the suburothelial layer [74,95]. Moreover, experiments with neurogenic electrical field stimulation of guinea-pig bladder tissue samples indicated that all subtypes of ICCs and smooth muscle cells displayed in situ spontaneous $\mathrm{Ca}^{2+}$ transients that were tetrodotoxin-sensitive [96]. 
In mouse preparations of the ureteropelvic junction, membrane depolarization of stellate ICLCs evoked a slowly developing outward current that did not arise from the opening of transient outward current or large conductance $\mathrm{Ca}^{2+}$-activated $\mathrm{K}^{+}$currents [97]. Whole-cell current-clamp recordings on ICLCs showed random fluctuations of membrane potential and occasionally large, long-lasting depolarizations, while voltage-clamp recordings showed high-frequency spontaneous transient inward currents, and the authors concluded that ICLCs could contribute to the ureteropelvic junction pacemaking in the absence of a pacemaker drive [97]. ICLCs from the lower urinary tract have been described to generate and propagate intracellular transient $\mathrm{Ca}^{2+}$ events [71].

However, the details of this $\mathrm{Ca}^{2+}$ spikes occurrence are still not well described, and a possible role of neuronal triggering can be considered since the ICCs react by means of calcium responses to the presence of external neurotransmitters.

\subsubsection{Calcium Signaling in Interstitial Cells of the Female Reproductive System}

Oxytocin-induced $\left[\mathrm{Ca}^{2+}\right]$ i oscillations have been demonstrated in primary cultures of human uterine myocytes $[98,99]$, but data recorded in intact cells residing within the myometrium are limited. However, a recent study on organotypic slices from human myometrium indicated that oxytocin-induced $\left[\mathrm{Ca}^{2+}\right]$ i oscillations occurred only in a proportion of cells and were not relevant for the acute regulation of myometrial contractility, but the authors suggested the involvement of $\left[\mathrm{Ca}^{2+}\right]$ i oscillations in long-term regulatory processes, e.g., gene expression triggering [100]. These cells were identified to be ICCs or ICLCs and described to be morphologically and phenotypically distinct by SMCs.

To date, the contribution of ICCs and/or ICLCs to the pacemaking activity was analyzed in different segments of the reproductive system. In murine oviducts, ICCs were described as pacemakers being responsible for generating slow waves underlying myosalpinx contractions that are critical for egg transport [101]. Additionally, calcium imaging of live tissue slices from myometrium show that ICLCs located on the edge of the smooth muscle bundles initiate the contractile wave [43]. Moreover, ICLCs from myometrium exhibit in vitro spontaneous electrical activity characterized by membrane potentials of $62.4 \pm 7.22 \mathrm{mV}$, and short duration: $1.197 \pm 0.04 \mathrm{~ms}$ [29]. More systematic experiments are necessary to confirm a detailed picture of calcium activity in the reproductive system ICCs.

\subsubsection{Calcium Signaling in Interstitial Cells of the Male Reproductive System}

Leydig cells are a subtype of interstitial cells that have been described in the seminiferous tubules of the testicles. BKCa channels were characterized to be activated by the increase of the intracellular $\mathrm{Ca}^{2+}$ and to determine the cell membrane hyperpolarization. In Leydig cells, the hyperpolarization induced by the BKCa channels was speculated to activate a series of events that limits testosterone production [102]. Oppositely, hormones might regulate the intracellular $\mathrm{Ca}^{2+}$ concentration in Leydig cells. To date, the luteinizing hormone was shown to modulate the T-type calcium channels and the intracellular $\mathrm{Ca}^{2+}$ transients through PKC and PKA signaling pathways, and thus, these kinases, besides the direct action to promote testosterone synthesis, also act on the overall calcium dynamics in Leydig cells [103]. Mibefradil was shown to inhibit T-type calcium channels in Leydig cells and steroidogenesis is linked to the $\mathrm{Ca}^{2+}$ entry through the T-type $\mathrm{Ca}^{2+}$ channel [104].

Exposure of Leydig cells to polychlorinated naphthalenes increased the intracellular $\mathrm{Ca}^{2+}$ concentration, the sex steroids production and the mRNA expression of estrogen-related receptors $\alpha, \beta$ and $\gamma$ [105]. Several studies pointed out that the $\mathrm{Ca}^{2+}$ molecular pathways are essential for steroidogenesis in Leydig cells and that the transcriptional cascade involving the nuclear receptor NR4A1 regulates steroidogenesis [106,107]. 


\subsubsection{Calcium Signaling in Interstitial Cells from the Vascular System}

Vascular interstitial cells from the portal vein were shown to play an important role in the rhythmic vascular activity that contributes to the vascular tone [108]. In particular, mitochondrial $\mathrm{Ca}^{2+}$ is essential for the generation of the rhythmic $\mathrm{Ca}^{2+}$ waves in vascular interstitial cells [108].

Vascular interstitial cells were discussed to be similar to the previously described ICCs and ICLCs $[35,109,110]$ and were characterized in a large variety of blood vessels preparations (e.g., rabbit portal vein and mesenteric and cerebral arteries; rat portal vein, aorta and pulmonary, mesenteric, kidney, coronary and cerebral arteries; mouse aorta, mesenteric and cerebral arteries; guinea pig cerebral, portal vein, mesenteric and kidney arteries; and human mesenteric and gastro-omental arteries) [35,111-116]. It should be emphasized that in primary vascular cell cultures, vascular interstitial cells display slow rhythmical changes of the intracellular $\mathrm{Ca}^{2+}$ concentration, while contractile vascular smooth muscle cells present faster $\mathrm{Ca}^{2+}$ sparks [109], and that both subtypes of $\mathrm{Ca}^{2+}$ signals are generated close to the apposition between the perinuclear $\mathrm{Ca}^{2+}$ store and endoplasmic reticulum network [110,117].

\subsection{Pathological Role of Calcium Signaling in Interstitial Cells}

3.2.1. Modulation of Calcium Signaling Pathways in Interstitial Cells as a Therapeutic Strategy against Aortic Valve Calcification and Aortic Stenosis

Valve interstitial cells have been extensively studied. The comparison between the transcriptional profiles and cellular functions of the human aortic valve interstitial cells and mitral valve interstitial cells indicated expression differences for seventy-eight genes, among those NKX2-5, TBX15, OGN, $O M D$, and $C D K N 1 C$ having a higher expression and TBX5, MMP1, and PCDH10 a lower expression in aortic valve interstitial cells [118]. Interestingly, mitral interstitial cells proliferated more quickly and showed more calcium deposition and alkaline phosphatase activity than aortic interstitial cells [118].

Calcific aortic valve disease is a slowly progressive disorder that ranges from aortic sclerosis to severe calcification, with multiple microscopic characteristics, including endothelial damage and lipid deposition. Valvular interstitial cells are thought to be involved in tissue remodeling and repair during the cyclic movement and mechanical stress of aortic valves [119]. Valvular interstitial cells are located on the internal side of the heart valves, being different between the three cusps, and only a subpopulation of these cells are predisposed to calcification [120]. 
Table 1. Calcium signaling in interstitial cells. Calcium signaling mechanisms in interstitial cells are described and their contribution to the pacemaking activity is indicated. The main interstitial cells involved in the pacemaking activity of different anatomical systems are ICCs and ICLCs, while TCs are not able to act as pacemakers. Other subtypes of interstitial cells (e.g., valve interstitial cells or Leydig cells) have not been described to play a role in pacemaking activity.

\begin{tabular}{|c|c|c|c|c|}
\hline $\begin{array}{l}\text { Anatomical } \\
\text { Localization of the } \\
\text { Interstitial Cells }\end{array}$ & $\begin{array}{c}\text { Subtype of } \\
\text { Interstitial Cells }\end{array}$ & Calcium Signaling Mechanisms & $\begin{array}{l}\text { Contribution to the } \\
\text { Pacemaking Activity }\end{array}$ & Reference \\
\hline $\begin{array}{l}\text { Gastrointestinal } \\
\text { system }\end{array}$ & ICCs & $\begin{array}{l}\text { - ICCs are coupled with SMCs and affect their resting membrane potential; gastrointestinal distension induces } \\
\text { sustained inward holding current via actin microfilaments and the process is mediated by changes in the } \\
\text { intracellular basal } \mathrm{Ca}^{2+} \text { concentration and } \mathrm{Ca}^{2+} \text { oscillations in ICCs }\end{array}$ & Yes & {$[63,90]$} \\
\hline \multirow{2}{*}{ Urinary system } & ICCs & $\begin{array}{l}\text { - ICCs present abundant calcium-activated chloride currents; ICCs contribute to the urethral tone and the } \\
\text { maintenance of urinary continence, and there is an important contribution of intracellular } \mathrm{Ca}^{2+} \text { stores and } \mathrm{Ca}^{2+} \\
\text { influx to these mechanisms; ICC and SMCs display in situ spontaneous tetrodotoxin-sensitive } \mathrm{Ca}^{2+} \text { transients }\end{array}$ & $\begin{array}{l}\text { Yes/No (Depending } \\
\text { on the segment of the } \\
\text { urinary tract) }\end{array}$ & {$[74,93,96]$} \\
\hline & ICLCs & $\begin{array}{l}\text { membrane depolarization of ICLCs evokes slowly developing outward current but not the opening of } \\
\text { transient outward current or large conductance } \mathrm{Ca}^{2+} \text {-activated } \mathrm{K}^{+} \text {currents; } \mathrm{ICLCs} \text { from the lower urinary } \\
\text { tract have been described to generate and propagate intracellular transient } \mathrm{Ca}^{2+} \text { events }\end{array}$ & Yes & {$[71,97]$} \\
\hline \multirow{4}{*}{ Reproductive system } & ICCs & - oviduct ICCs generate slow waves underlying myosalpinx contractions that are critical for egg transport & Yes & [101] \\
\hline & ICLCs & $\begin{array}{l}\text { - myometrial contractile signaling, associated with } \mathrm{Ca}^{2+} \text { intracellular transients, starts on the borders of smooth } \\
\text { muscle bundles where ICLC are located; myometrial ICLCs present in vitro spontaneous electrical activity }\end{array}$ & Yes & {$[29,43]$} \\
\hline & TCs & $\begin{array}{l}\text { TCs do not express key pacemaker genes (e.g., Kit, Ano1); T-type calcium channels were described to } \\
\text { contribute to the mechanical sensing of TCs; hyperpolarization-activated chloride inward currents with } \\
\text { calcium dependence and small-conductance calcium-activated potassium currents were described in TCs }\end{array}$ & No & {$[68,121-123]$} \\
\hline & Leydig cells & $\begin{array}{l}\text { - the hyperpolarization induced by the BKCa channels was speculated to activate a series of events that limits } \\
\text { testosterone production; steroidogenesis is linked to the } \mathrm{Ca}^{2+} \text { entry through the T-type } \mathrm{Ca}^{2+} \text { channel }\end{array}$ & $\mathrm{N} / \mathrm{A}$ & {$[102-104,106,107]$} \\
\hline \multirow{3}{*}{$\begin{array}{l}\text { Cardiovascular } \\
\text { system }\end{array}$} & $\begin{array}{l}\text { Vascular interstitial } \\
\text { cells }\end{array}$ & $\begin{array}{l}\text { vascular interstitial cells (similar to ICCs/ICLCs) display slow rhythmical changes of the intracellular } \mathrm{Ca}^{2+} \\
\text { concentration that imply both the contribution of the perinuclear } \mathrm{Ca}^{2+} \text { store and endoplasmic } \\
\text { reticulum network }\end{array}$ & Yes & {$[110,113,117]$} \\
\hline & TCs & - vascular TCs express large conductance BKCa and inwardly rectifying $\mathrm{K}^{+}$currents & Probably yes & [124] \\
\hline & $\begin{array}{l}\text { Valve interstitial } \\
\text { cells }\end{array}$ & $\begin{array}{l}\text { - valve interstitial cells are involved in tissue remodeling and repair during the cyclic movement and } \\
\text { mechanical stress of aortic valves, but in pathological conditions are predisposed to calcification }\end{array}$ & $\mathrm{N} / \mathrm{A}$ & [120] \\
\hline
\end{tabular}


In aortic valve interstitial cells, rapamycin, a commonly used immunosuppressant, was described to inhibit Toll-like receptor 4 (TLR4)-induced osteogenic responses by activation of signal transducer and activator of transcription 3 (Stat3) through Akt, and to alleviate the inflammation-induced initiation and progression of calcific aortic valve disease [125].

Denosumab, a human monoclonal antibody that binds the receptor activator of nuclear factor $\kappa-\beta$ ligand, was shown to reduce calcium deposition in the aorta [126], but the mechanism by which it affects ectopic calcification was poorly understood in the last decade. A recent study highlighted that denosumab may act as an in vitro inhibitor of valvular interstitial cells calcification [127].

\subsubsection{Interstitial Cells Dysfunction during Intestinal Inflammation}

ICCs play an important role in the gastrointestinal inflammation. Inflammation-induced alterations in the network of ICCs from the small intestine associated with Auerbach's plexus lead to gastrointestinal motility disturbances [128]. Recently, it was demonstrated that during the intestinal inflammation, nitric oxide-induced oxidative stress impaired the pacemaking function of murine ICCs [129]. Indeed, treatment of ICCs with interferon- $\gamma$ and lipopolysaccharides for $24 \mathrm{~h}$ reduced the frequency and the amplitude of calcium oscillations in these cells [129]. However, the possibility of a direct action of cytokines on ICCs during the inflammatory process could be another explanation.

\section{Calcium Signaling in TCs}

TCs are ubiquitous cells localized in the various mammalian anatomical structures, e.g., cardiovascular, respiratory, digestive, reproductive, urinary, musculoskeletal, integumentary, visual, nervous, and hematopoietic systems [130]. However, the study of calcium signaling in TCs is a recently opened research direction. The pioneering studies done so far have been rather focused on the description of calcium channels at the plasma membrane level by immunohistochemistry and electrophysiology techniques. This topic has many uncovered aspects to be further investigated. Actually, there are no papers reporting direct evidence of calcium transients in TCs. In the following paragraphs, we review the very little information reported until now on this topic.

\subsection{Physiological Role of Calcium Signaling in TCs}

\subsubsection{Contribution of Calcium Signaling in TCs to the Uterine Physiology}

A novel class of PDGFR- $\alpha(+)$ interstitial cells was described in mouse and monkey female reproductive tracts. It is distinct from smooth muscle cells and ICCs, and was characterized to have a variable gene expression between parts of the reproductive tract (e.g., ovary, oviduct, and uterus) or between the tissue regions of the same organ (e.g., uterine myometrium vs. endometrium) [131]. These cells are unlikely to provide pacemaker activity, as key pacemaker genes found in ICCs (e.g., Kit, and Ano1) [121,132] were not detected to be expressed, while the Gja1 gene encoding for connexin 43 was identified in high levels suggesting their possible involvement in forming gap junctions in between and with the neighboring smooth muscle cells [131]. CD34 and PDGFR $\alpha$ are considered as reliable markers to identify and separate TCs $[47,133,134]$ and we might suppose that the newly identified interstitial cells are corresponding to TCs.

Recent studies have described by immunohistochemistry and in vitro electrophysiology the presence of T-type calcium channels in cultured human myometrial TCs $[68,123]$. Cretoiu et al. reported difficulties in recording T-type calcium channels in human myometrial TCs by applying the standard patch-clamp protocol consisting in step depolarization pulses from -90 to $+40 \mathrm{mV}$ of $100 \mathrm{~ms}$ duration, $10-\mathrm{mV}$ increment from a holding potential of $-110 \mathrm{mV}$ [68]. However, the authors succeeded to activate T-type calcium currents in human myometrial TCs by applying a brief depolarizing ramp protocol from -90 to $+60 \mathrm{mV}$ with a duration of $100 \mathrm{~ms}$ and steepness of $1.5 \mathrm{~V} / \mathrm{s}$ [68]. Mibefradil, a selective inhibitor of T-type calcium channels, was demonstrated to block these currents in uterine TCs [68]. Additionally, acute (30 $\mathrm{min})$ and chronic $(24 \mathrm{~h})$ exposure of TCs from pregnant myometrium 
to mibefradil determined a significant reduction in the low-level laser stimulation telopodal lateral extension growth rate [123].

TCs are considered as mechanical sensors in human uterus, probably being involved in the detection and translation of the stretch stimuli to the nuclear factors and in the activation of genes encoding protein synthesis $[135,136]$. We might suppose that calcium signaling in uterine TCs plays an important role in the mechanical sensing mechanism, as mibefradil was already shown to distinctly modulate TCs sensitivities from nonpregnant and pregnant myometrium to low-level laser stimulation [123]. As TCs from pregnant myometrium were more susceptible to deviate the growth direction of telopodal lateral extension than those from nonpregnant myometrium when exposed to low-laser laser stimulation [123], then these cells were proposed to play an important role in the uterine contraction mechanism in a direct relationship with the pregnancy status [136].

The physiological role of calcium signaling in TCs should be considered in an extended perspective as multiple ion channels are calcium-activated and/or calcium-dependent. In this context, previous studies have also reported the functional expression of hyperpolarization-activated chloride inward current with calcium dependence [122] and of small-conductance calcium-activated potassium (SK3) channels [137] in cultivated TCs from human myometrium. Interestingly, uterine TCs, but not uterine smooth muscle cells, were demonstrated to express SK3 channels, and that this expression is higher in nonpregnant compared to pregnant myometrium [137]. Moreover, SK3 activators were proposed to reduce contractility in human myometrium by modulating TCs function [137]. NS4591 (4,5-dichloro-1,3-diethyl-1,3-dihydro-benzoimidazol-2-one) is also a modulator of the calcium-activated potassium channels and was demonstrated to exert a relaxant effect on the human myometrial spontaneous contractility in vitro [138].

\subsubsection{Contribution of Calcium Signaling in TCs to the Cardiac Physiology}

Oppositely to the uterine TCs that do not express the pacemaker-related Kit and Ano1 genes [131], cardiac TCs express CD34, CD29, vimentin, sca-1, c-kit, and Nanog, and are more likely to be involved in the heart pacemaking activity $[133,139,140]$. Additionally, cardiac TCs were demonstrated to functionally express large conductance $\mathrm{Ca}^{2+}$-activated $\mathrm{K}^{+}$currents (BKCa) and inwardly rectifying $\mathrm{K}^{+}$ currents, but not transient outward $\mathrm{K}^{+}$currents or ATP-sensitive potassium current [124]. The presence of BKCa channels in cardiac TCs strongly supports the involvement of these cells in the cardiac pacemaking activity, as previous studies have demonstrated that BKCa channels regulate sinoatrial node firing rate and cardiac pacing in vivo [141].

\subsubsection{Contribution of Calcium Signaling in TCs to the Urinary Physiology}

Several subtypes of TCs have been described in the human urinary bladder: (i) TCs from the sub-urothelium were PDGFR $\alpha$ /calret-positive and CD34/c-Kit-negative, being subdivided in $\alpha$ SMA-negative if located immediately beneath the urothelium, and $\alpha$ SMA-positive when located deeper and having a larger body; and (ii) TCs from the submucosa and detrusor were PDGFR $\alpha / \alpha$ SMA /c-Kit-negative and CD34/calret-positive [38]. The authors mentioned that no cell possessing the ICCs features was detected, while TCs were organized in a thick multilayered area parallel to the urothelial surface [38]. Despite the characterization of TCs in the urinary system or the already described role of $\mathrm{Ca}^{2+}$ signaling contribution to the urethral tone and urinary continence maintenance in ICCs and ICLCs $[71,74,93,96,97]$, no studies have described so far the calcium signaling mechanisms in TCs from different segments of the urinary system.

\subsection{Pathological Role of Calcium Signaling in TCS}

\subsubsection{Contribution of Calcium Signaling in TCs to the Immune Response}

Uterine TCs were described as functional players in the activation of peritoneal macrophages. Macrophages exposed to TC conditioned media contained abundant pseudopodia and cytoplasmic 
secretory granules without cell viability changes, and had an increased release of TNF- $\alpha$, IL1-R1, and IL-10, but not TGF- $\beta 1$, IL-1 $\beta$, IL-23 $\alpha$, and IL-18 [142]. Based on the in vitro data, it was suggested that TCs are involved in the immune response, being important actors in the immunoregulatory and immunosurveillance processes [142].

Additionally to the already known involvement of the Langerhans cells, dermal dendritic cells, inflammatory dendritic epidermal cells and plasmacytoid dendritic cells in the chronic skin inflammatory process that characterizes psoriasis, recently, dermal TCs were described to be one of the important triggers for the characteristic vascular pathology in psoriasis [143]. Previous studies in psoriasis indicated alterations of the calcium metabolism in several cellular systems, and, consequently, we might suppose that TCs, as part of the immune system activation, undergo significant changes in calcium signaling changes. To date, cultured psoriatic keratinocytes present a down regulation of the capacitive calcium influx and a defective calcium-mediated cell signaling [144]. In a model of psoriasis-inflamed skin, it was proved that store-operated calcium entry proteins, e.g., stromal interaction molecule (STIM1), contribute to neutrophil chemotaxis and infiltration [145]. Moreover, there is a strong positive association between psoriasis and an increased coronary calcium score, mainly in patients with severe psoriasis [146] and hypocalcemia is considered as a risk factor in this pathology [147].

\subsubsection{Correlations between Elements that Modulate TCs Migration and Various Pathologies}

A recently proposed theoretical model described TCs migration in chemical, metabolic and heat gradients [55]. Increased metabolism can be found in pathological cases such as tumors [148] or infections [149], but also in tissues with increased metabolic activity, e.g., striated muscle [150], cardiac muscle [151] or myometrium in different physiological [152] or pathological states [153].

Involvement of TCs signaling through calcium and increased metabolism limits the use of TCs calcium channel modulators in the pathologies affecting the heart and uterine muscles, due to a relatively uniform signaling pathway through calcium in these organs.

\subsubsection{TCs and Possible Roles of Calcium Metabolism in Uterine Pathologies}

Modulation of TCs' growth by mechanical factors via calcium channels has a degree of mechanical sensitivity [123] and correlates with the TCs' ability to communicate through gap junctions [40,46], the calcium involvement in myometrium proliferation [154,155] and contraction [100]. Therefore, we propose the hypothesis that TCs contribute to smooth muscle growth in areas with high mechanical forces. This signaling mechanism may be involved in the uniform growth of uterus thickness during pregnancy by signaling the increase in thickness of the uterus in all areas with a thinner uterine wall compared with adjacent areas. This uniform growth is also modulated by normal uterine contractions. Promising therapeutic outputs include the prevention of uterine ruptures secondary to uterine hypotrophy, by employing calcium channels modulators acting on TCs. Implantation of the placenta leads to its development into the uterine wall thickness. This process decreases the thickness of the myometrium in the area with the maximum development of the placenta. This increases the mechanical forces generated by the mass of the fetus and myometrium physiological contractions in these localized areas. TCs may be involved in these areas with a compensatory increase in the thickness of the uterus, through the mechanism described above. It opens up new therapeutic opportunities for the treatment of pathological implantation of the placenta.

\subsubsection{TCs and Possible Roles of Calcium Metabolism in Cardiac Pathologies}

Concentric muscle growth of the cavitary organs modulated by mechanical forces and calcium through the mechanism described above could justify various forms of cardiac hypertrophy (concentric and eccentric) by correlations between mechanical forces, the degree of local fibrosis that could decrease the stimulation of TCs through stretching and the degree of perfusion that is needed to hypertrophy. 
This theoretical model explains the link between high cardiac fibrosis after myocardial infarction and functional recovery [156].

\section{Concluding Remarks and Perspectives}

To summarize, comparing the role of calcium signaling mechanisms in different subtypes of interstitial cells to the pacemaking activity (Figure 4), we conclude that while ICCs and ICLCs are contributing to the initiation and propagation of the $\mathrm{Ca}^{2+}$ oscillations, TCs are not pacemakers but modulate the activity of the surrounding cells. However, this conclusion has to be confirmed by future reports on calcium signaling mechanisms, especially in the case of TCs.

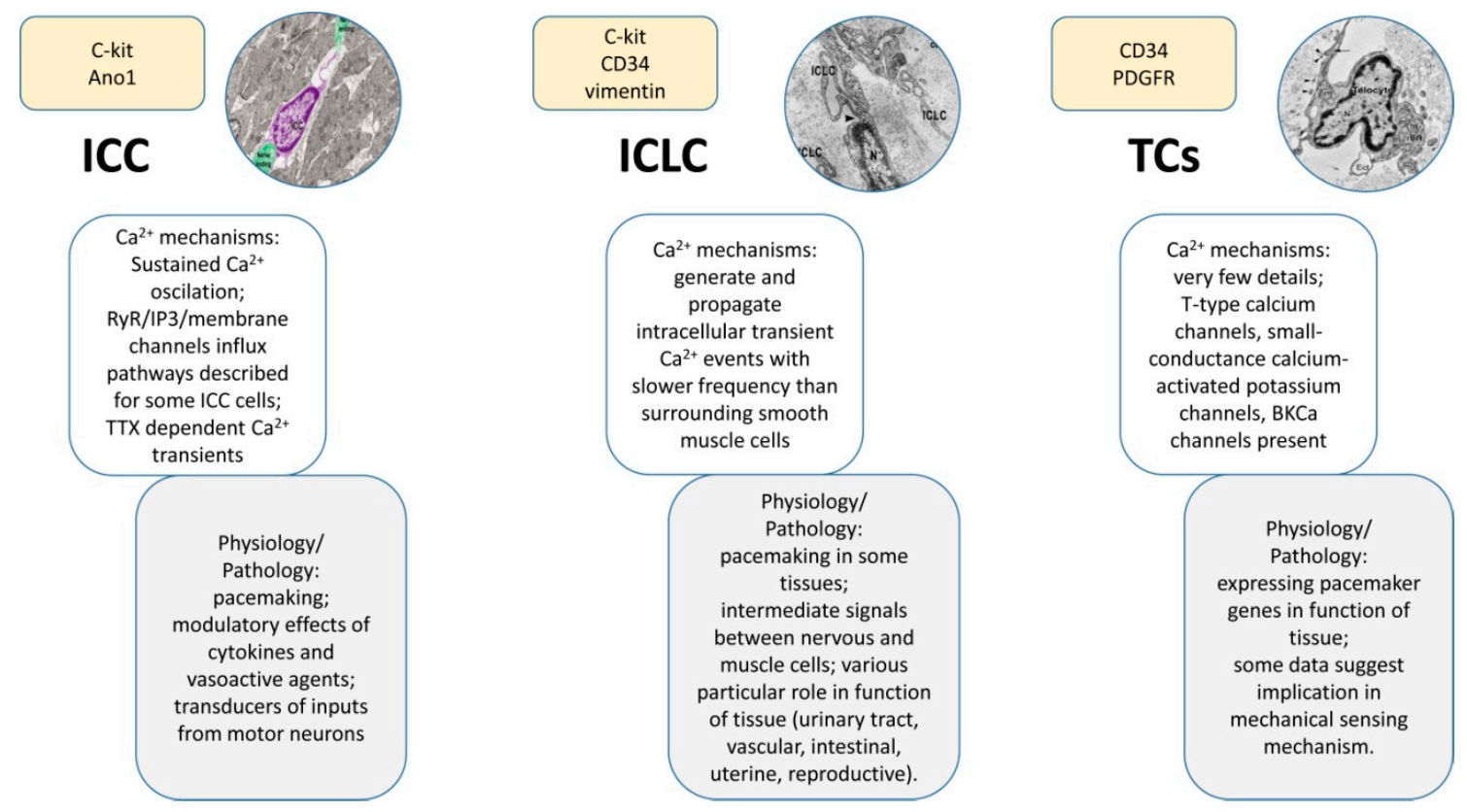

Figure 4. Compendious comparison of main features among the three types of cells described here: ICCs, ICLCs, and TCs. Knowledge about calcium signaling and related physiological processes are highlighted. As expected, the ICCs are the best described and the TCs the poorest. One can observe certain similarities between the ICLCs and the other two types of cells, explained by the fact that both cell populations co-exist under this acronym. Insets reproduced with permission from [44,157].

Moreover, even if the role of ICCs to intermediate the information transmission from neurons to surrounding muscles cells is largely accepted, the possibility that neurotransmitters (able to trigger the cascades controlling $\mathrm{Ca}^{2+}$ in ICCs) are involved in the peacemaking activity is very little explored. We consider that this hypothesis could be tested in future works.

Although the existence of TCs signaling mechanisms with neighboring cells using signaling through calcium is incompletely understood, these cells open great therapeutic opportunities especially for predominantly muscular organs, which have a high degree of uniformity in the response to calcium. Muscle growth control mechanisms depending on TCs' ability to respond to mechanical stimuli mediated by calcium channels were highlighted. Targeting these channels of TCs can lead to the development of innovative therapies for diseases with significant social and economic impacts, such as uterine pathologies and abnormal implantation of the placenta, or cardiac pathologies like hypertrophy and response to myocardial infarction. For this goal, it is necessary to develop viable ways for TCs' separation from biological samples to allow calcium channel targeted overexpression, or expression of calcium channels modified to respond to specific drugs. Such an approach would reduce potential side effects of low specificity calcium channel modulators. 
Acknowledgments: This work was partially supported by grants from the Romanian National Authority for Scientific Research, CNCS-UEFISCDI, projects number 82/2012 and 194/2014. B.M. Radu has a Ph.D. fellowship from the Italian Ministry of Research (MIUR). We thank Florentina Ghiroaga for proofreading this paper.

Conflicts of Interest: The authors declare no conflict of interest.

\section{References}

1. Vannucchi, M.G.; Traini, C. Interstitial cells of cajal and telocytes in the gut: Twins, related or simply neighbor cells? Biomol. Concepts 2016, 7, 93-102. [CrossRef] [PubMed]

2. Mongkoldhumrongkul, N.; Yacoub, M.; Chester, A. Valve endothelial cells-Not just any old endothelial cells. Curr. Vasc. Pharmacol. 2016, 14, 146-154. [CrossRef] [PubMed]

3. Kaissling, B.; Le Hir, M. The renal cortical interstitium: Morphological and functional aspects. Histochem. Cell Biol. 2008, 130, 247-262. [CrossRef] [PubMed]

4. Svechnikov, K.; Landreh, L.; Weisser, J.; Izzo, G.; Colon, E.; Svechnikova, I.; Soder, O. Origin, development and regulation of human leydig cells. Horm. Res. Paediatr. 2010, 73, 93-101. [CrossRef] [PubMed]

5. Komuro, T.; Tokui, K.; Zhou, D.S. Identification of the interstitial cells of cajal. Histol. Histopathol. 1996, 11, 769-786. [PubMed]

6. Cajal, S.R. Les preuves objectives de lúnite anatomiquedes cellules nerveuses. Trav. Lab. Rech. Biol. Univ. Madrid. 1934, 29, 1-137.

7. Thuneberg, L. One hundred years of interstitial cells of cajal. Microsc. Res. Tech. 1999, 47, 223-238. [CrossRef]

8. Faussone, P.M.; Cortesini, C.; Romagnoli, P. Ultrastructure of the tunica muscularis of the cardial portion of the human esophagus and stomach, with special reference to the so-called cajal's interstitial cells. Arch. Ital. Anat. Embriol. 1977, 82, 157-177.

9. Faussone-Pellegrini, M.S.; Thuneberg, L. Guide to the identification of interstitial cells of cajal. Microsc. Res. Tech. 1999, 47, 248-266. [CrossRef]

10. Komuro, T. Comparative morphology of interstitial cells of cajal: Ultrastructural characterization. Microsc. Res. Tech. 1999, 47, 267-285. [CrossRef]

11. Christensen, J. A commentary on the morphological identification of interstitial cells of Cajal in the gut. J. Auton. Nerv. Syst. 1992, 37, 75-88. [CrossRef]

12. Epperson, A.; Hatton, W.J.; Callaghan, B.; Doherty, P.; Walker, R.L.; Sanders, K.M.; Ward, S.M.; Horowitz, B. Molecular markers expressed in cultured and freshly isolated interstitial cells of cajal. Am. J. Physiol. Cell Physiol. 2000, 279, C529-C539. [PubMed]

13. Grider, J.R. Focus on "Molecular markers expressed in cultured and freshly isolated interstitial cells of Cajal". Am. J. Physiol. Cell Physiol. 2000, 279, C284-C285. [PubMed]

14. Takeda, M.; Takayama, I.; Terada, N.; Baba, T.; Ward, S.M.; Ohno, S.; Fujino, M.A. Immunoelectronmicroscopic study of Kit-expressing cells in the jejunum of wildtype and Ws/Ws rats. Cell Tissue Res. 2001, 304, 21-30. [CrossRef]

15. Iino, S.; Horiguchi, K.; Nojyo, $\mathrm{Y} . \mathrm{W}^{\text {sh }} / \mathrm{W}^{\text {sh }} \mathrm{c}-\mathrm{Kit}$ mutant mice possess interstitial cells of Cajal in the deep muscular plexus layer of the small intestine. Neurosci. Lett. 2009, 459, 123-126. [CrossRef] [PubMed]

16. Chen, H.; Ordog, T.; Chen, J.; Young, D.L.; Bardsley, M.R.; Redelman, D.; Ward, S.M.; Sanders, K.M. Differential gene expression in functional classes of interstitial cells of Cajal in murine small intestine. Physiol. Genom. 2007, 31, 492-509. [CrossRef] [PubMed]

17. Gomez-Pinilla, P.J.; Gibbons, S.J.; Bardsley, M.R.; Lorincz, A.; Pozo, M.J.; Pasricha, P.J.; van de Rijn, M.; West, R.B.; Sarr, M.G.; Kendrick, M.L.; et al. Ano1 is a selective marker of interstitial cells of cajal in the human and mouse gastrointestinal tract. Am. J. Physiol. 2009, 296, G1370-G1381. [CrossRef] [PubMed]

18. Sanders, K.M. A case for interstitial cells of cajal as pacemakers and mediators of neurotransmission in the gastrointestinal tract. Gastroenterology 1996, 111, 492-515. [CrossRef] [PubMed]

19. Ward, S.M.; Ordog, T.; Koh, S.D.; Baker, S.A.; Jun, J.Y.; Amberg, G.; Monaghan, K.; Sanders, K.M. Pacemaking in interstitial cells of cajal depends upon calcium handling by endoplasmic reticulum and mitochondria. J. Physiol. 2000, 525, 355-361. [CrossRef] [PubMed]

20. Hirst, G.D.; Bramich, N.J.; Teramoto, N.; Suzuki, H.; Edwards, F.R. Regenerative component of slow waves in the guinea-pig gastric antrum involves a delayed increase in $\left[\mathrm{Ca}^{2+}\right]_{\mathrm{i}}$ and $\mathrm{Cl}^{-}$channels. J. Physiol. 2002, 540, 907-919. [CrossRef] [PubMed] 
21. Edwards, F.R.; Hirst, G.D. An electrical analysis of slow wave propagation in the guinea-pig gastric antrum. J. Physiol. 2006, 571, 179-189. [CrossRef] [PubMed]

22. Pezzone, M.A.; Watkins, S.C.; Alber, S.M.; King, W.E.; de Groat, W.C.; Chancellor, M.B.; Fraser, M.O. Identification of c-Kit-positive cells in the mouse ureter: The interstitial cells of Cajal of the urinary tract. Am. J. Physiol. 2003, 284, F925-F929. [CrossRef] [PubMed]

23. Shafik, A.; El-Sibai, O.; Shafik, A.A.; Shafik, I. Identification of interstitial cells of Cajal in human urinary bladder: Concept of vesical pacemaker. Urology 2004, 64, 809-813. [CrossRef] [PubMed]

24. Turunc, T.; Bayazit, Y.; Doran, F.; Bal, N.; Doran, S. Effects of vas deferens obstruction on cajal-like cells in rats. Urol. Int. 2009, 83, 86-91. [CrossRef] [PubMed]

25. Lang, R.J.; Klemm, M.F. Interstitial cell of cajal-like cells in the upper urinary tract. J. Cell. Mol. Med. 2005, 9, 543-556. [CrossRef] [PubMed]

26. Lang, R.J.; Tonta, M.A.; Zoltkowski, B.Z.; Meeker, W.F.; Wendt, I.; Parkington, H.C. Pyeloureteric peristalsis: Role of atypical smooth muscle cells and interstitial cells of cajal-like cells as pacemakers. J. Physiol. 2006, 576, 695-705. [CrossRef] [PubMed]

27. Di Benedetto, A.; Arena, S.; Nicotina, P.A.; Mucciardi, G.; Gali, A.; Magno, C. Pacemakers in the upper urinary tract. Neurourol. Urodyn. 2013, 32, 349-353. [CrossRef] [PubMed]

28. Feeney, M.M.; Rosenblum, N.D. Urinary tract pacemaker cells: Current knowledge and insights from nonrenal pacemaker cells provide a basis for future discovery. Pediatr. Nephrol. 2014, 29, 629-635. [CrossRef] [PubMed]

29. Ciontea, S.M.; Radu, E.; Regalia, T.; Ceafalan, L.; Cretoiu, D.; Gherghiceanu, M.; Braga, R.I.; Malincenco, M.; Zagrean, L.; Hinescu, M.E.; et al. C-kit immunopositive interstitial cells (cajal-type) in human myometrium. J. Cell. Mol. Med. 2005, 9, 407-420. [CrossRef] [PubMed]

30. Popescu, L.M.; Hinescu, M.E.; Ionescu, N.; Ciontea, S.M.; Cretoiu, D.; Ardelean, C. Interstitial cells of cajal in pancreas. J. Cell. Mol. Med. 2005, 9, 169-190. [CrossRef] [PubMed]

31. Shafik, A.; El-Sibai, O.; Shafik, I.; Shafik, A.A. Immunohistochemical identification of the pacemaker cajal cells in the normal human vagina. Arch. Gynecol. Obstetr. 2005, 272, 13-16. [CrossRef] [PubMed]

32. Popescu, L.M.; Ciontea, S.M.; Cretoiu, D.; Hinescu, M.E.; Radu, E.; Ionescu, N.; Ceausu, M.; Gherghiceanu, M.; Braga, R.I.; Vasilescu, F.; et al. Novel type of interstitial cell (cajal-like) in human fallopian tube. J. Cell. Mol. Med. 2005, 9, 479-523. [CrossRef] [PubMed]

33. Shafik, A.; Shafik, I.; el-Sibai, O. Identification of c-kit-positive cells in the human prostate: The interstitial cells of cajal. Arch. Androl. 2005, 51, 345-351. [CrossRef] [PubMed]

34. Radu, E.; Regalia, T.; Ceafalan, L.; Andrei, F.; Cretoiu, D.; Popescu, L.M. Cajal-type cells from human mammary gland stroma: Phenotype characteristics in cell culture. J. Cell. Mol. Med. 2005, 9, 748-752. [CrossRef] [PubMed]

35. Pucovsky, V.; Harhun, M.I.; Povstyan, O.V.; Gordienko, D.V.; Moss, R.F.; Bolton, T.B. Close relation of arterial icc-like cells to the contractile phenotype of vascular smooth muscle cell. J. Cell. Mol. Med. 2007, 11, 764-775. [CrossRef] [PubMed]

36. Diaz-Flores, L.; Gutierrez, R.; Garcia, M.P.; Saez, F.J.; Diaz-Flores, L., Jr.; Valladares, F.; Madrid, J.F. Cd34+ stromal cells/fibroblasts/fibrocytes/telocytes as a tissue reserve and a principal source of mesenchymal cells. Location, morphology, function and role in pathology. Histol. Histopathol. 2014, 29, 831-870. [PubMed]

37. Diaz-Flores, L.; Gutierrez, R.; Garcia, M.P.; Gonzalez, M.; Saez, F.J.; Aparicio, F.; Diaz-Flores, L., Jr.; Madrid, J.F. Human resident CD34+ stromal cells/telocytes have progenitor capacity and are a source of alphasma+ cells during repair. Histol. Histopathol. 2015, 30, 615-627. [PubMed]

38. Vannucchi, M.G.; Traini, C.; Guasti, D.; Del Popolo, G.; Faussone-Pellegrini, M.S. Telocytes subtypes in human urinary bladder. J. Cell. Mol. Med. 2014, 18, 2000-2008. [CrossRef] [PubMed]

39. Vannucchi, M.G.; Traini, C.; Manetti, M.; Ibba-Manneschi, L.; Faussone-Pellegrini, M.S. Telocytes express pdgfralpha in the human gastrointestinal tract. J. Cell. Mol. Med. 2013, 17, 1099-1108. [CrossRef] [PubMed]

40. Sanders, K.M.; Kito, Y.; Hwang, S.J.; Ward, S.M. Regulation of gastrointestinal smooth muscle function by interstitial cells. Physiology 2016, 31, 316-326. [CrossRef] [PubMed]

41. Popescu, L.M.; Faussone-Pellegrini, M.S. Telocytes-A case of serendipity: The winding way from interstitial cells of cajal (icc), via interstitial cajal-like cells (iclc) to telocytes. J. Cell. Mol. Med. 2010, 14, 729-740. [CrossRef] [PubMed]

42. Cretoiu, S.M.; Popescu, L.M. Telocytes revisited. Biomol. Concepts 2014, 5, 353-369. [CrossRef] [PubMed] 
43. Hutchings, G.; Williams, O.; Cretoiu, D.; Ciontea, S.M. Myometrial interstitial cells and the coordination of myometrial contractility. J. Cell. Mol. Med. 2009, 13, 4268-4282. [CrossRef] [PubMed]

44. Cretoiu, D.; Cretoiu, S.M.; Simionescu, A.A.; Popescu, L.M. Telocytes, a distinct type of cell among the stromal cells present in the lamina propria of jejunum. Histol. Histopathol. 2012, 27, 1067-1078. [PubMed]

45. Cretoiu, S.M.; Cretoiu, D.; Popescu, L.M. Human myometrium-The ultrastructural 3d network of telocytes. J. Cell. Mol. Med. 2012, 16, 2844-2849. [CrossRef] [PubMed]

46. Cretoiu, D.; Xu, J.; Xiao, J.; Cretoiu, S.M. Telocytes and their extracellular vesicles-evidence and hypotheses. Int. J. Mol. Sci. 2016, 17, 1322. [CrossRef] [PubMed]

47. Song, D.; Cretoiu, D.; Cretoiu, S.M.; Wang, X. Telocytes and lung disease. Histol. Histopathol. 2016, 31, 1303-1314. [PubMed]

48. Zheng, M.; Sun, X.; Zhang, M.; Qian, M.; Zheng, Y.; Li, M.; Cretoiu, S.M.; Chen, C.; Chen, L.; Cretoiu, D.; et al. Variations of chromosomes 2 and 3 gene expression profiles among pulmonary telocytes, pneumocytes, airway cells, mesenchymal stem cells and lymphocytes. J. Cell. Mol. Med. 2014, 18, 2044-2060. [CrossRef] [PubMed]

49. Sun, X.; Zheng, M.; Zhang, M.; Qian, M.; Zheng, Y.; Li, M.; Cretoiu, D.; Chen, C.; Chen, L.; Popescu, L.M.; et al. Differences in the expression of chromosome 1 genes between lung telocytes and other cells: Mesenchymal stem cells, fibroblasts, alveolar type ii cells, airway epithelial cells and lymphocytes. J. Cell. Mol. Med. 2014, 18, 801-810. [CrossRef] [PubMed]

50. Song, D.; Cretoiu, D.; Zheng, M.; Qian, M.; Zhang, M.; Cretoiu, S.M.; Chen, L.; Fang, H.; Popescu, L.M.; Wang, X. Comparison of chromosome 4 gene expression profile between lung telocytes and other local cell types. J. Cell. Mol. Med. 2016, 20, 71-80. [CrossRef] [PubMed]

51. Zheng, Y.; Cretoiu, D.; Yan, G.; Cretoiu, S.M.; Popescu, L.M.; Fang, H.; Wang, X. Protein profiling of human lung telocytes and microvascular endothelial cells using itraq quantitative proteomics. J. Cell. Mol. Med. 2014, 18, 1035-1059. [CrossRef] [PubMed]

52. Albulescu, R.; Tanase, C.; Codrici, E.; Popescu, D.I.; Cretoiu, S.M.; Popescu, L.M. The secretome of myocardial telocytes modulates the activity of cardiac stem cells. J. Cell. Mol. Med. 2015, 19, 1783-1794. [CrossRef] [PubMed]

53. Cismasiu, V.B.; Radu, E.; Popescu, L.M. Mir-193 expression differentiates telocytes from other stromal cells. J. Cell. Mol. Med. 2011, 15, 1071-1074. [CrossRef] [PubMed]

54. Zheng, Y.; Zhang, M.; Qian, M.; Wang, L.; Cismasiu, V.B.; Bai, C.; Popescu, L.M.; Wang, X. Genetic comparison of mouse lung telocytes with mesenchymal stem cells and fibroblasts. J. Cell. Mol. Med. 2013, 17, 567-577. [CrossRef] [PubMed]

55. Cretoiu, D.; Radu, B.M.; Banciu, A.; Banciu, D.D.; Cretoiu, S.M. Telocytes heterogeneity: From cellular morphology to functional evidence. Semin. Cell Dev. Biol. 2016. [CrossRef] [PubMed]

56. Iino, S.; Horiguchi, K. Interstitial cells of cajal are involved in neurotransmission in the gastrointestinal tract. Acta Histochem. Cytochem. 2006, 39, 145-153. [CrossRef] [PubMed]

57. Burnstock, G.; Lavin, S. Interstitial cells of cajal and purinergic signalling. Auton Neurosci. 2002, 97, 68-72. [CrossRef]

58. Kim, B.J.; Park, K.J.; Kim, H.W.; Choi, S.; Jun, J.Y.; Chang, I.Y.; Jeon, J.H.; So, I.; Kim, S.J. Identification of trpm7 channels in human intestinal interstitial cells of cajal. World J. Gastroenterol. 2009, 15, 5799-5804. [CrossRef] [PubMed]

59. Johnston, L.; Sergeant, G.P.; Hollywood, M.A.; Thornbury, K.D.; McHale, N.G. Calcium oscillations in interstitial cells of the rabbit urethra. J. Physiol. 2005, 565, 449-461. [CrossRef] [PubMed]

60. Berridge, M.J. Calcium signal transduction and cellular control mechanisms. Biochim. Biophys. Acta 2004, 1742, 3-7. [CrossRef] [PubMed]

61. Berridge, M.J. Inositol trisphosphate and calcium signalling mechanisms. Biochim. Biophys. Acta 2009, 1793, 933-940. [CrossRef] [PubMed]

62. Berridge, M.J. Smooth muscle cell calcium activation mechanisms. J. Physiol. 2008, 586, 5047-5061. [CrossRef] [PubMed]

63. Sanders, K.M.; Koh, S.D.; Ward, S.M. Interstitial cells of cajal as pacemakers in the gastrointestinal tract. Ann. Rev. Physiol. 2006, 68, 307-343. [CrossRef] [PubMed] 
64. Baker, S.A.; Drumm, B.T.; Saur, D.; Hennig, G.W.; Ward, S.M.; Sanders, K.M. Spontaneous Ca(2+) transients in interstitial cells of cajal located within the deep muscular plexus of the murine small intestine. J. Physiol. 2016, 594, 3317-3338. [CrossRef] [PubMed]

65. Zhu, M.H.; Sung, T.S.; O’Driscoll, K.; Koh, S.D.; Sanders, K.M. Intracellular Ca(2+) release from endoplasmic reticulum regulates slow wave currents and pacemaker activity of interstitial cells of cajal. Am. J. Physiol. 2015, 308, C608-C620. [CrossRef] [PubMed]

66. Beyder, A.; Farrugia, G. Targeting ion channels for the treatment of gastrointestinal motility disorders. Therap. Adv. Gastroenterol. 2012, 5, 5-21. [CrossRef] [PubMed]

67. Zhou, J.J.; Linsdell, P. Evidence that extracellular anions interact with a site outside the cftr chloride channel pore to modify channel properties. Can. J. Physiol. Pharmacol. 2009, 87, 387-395. [CrossRef] [PubMed]

68. Cretoiu, S.M.; Radu, B.M.; Banciu, A.; Banciu, D.D.; Cretoiu, D.; Ceafalan, L.C.; Popescu, L.M. Isolated human uterine telocytes: Immunocytochemistry and electrophysiology of t-type calcium channels. Histochem. Cell Biol. 2015, 143, 83-94. [CrossRef] [PubMed]

69. Hashitani, H.; Lang, R.J. Functions of icc-like cells in the urinary tract and male genital organs. J. Cell. Mol. Med. 2010, 14, 1199-1211. [CrossRef] [PubMed]

70. Lang, R.J.; Hashitani, H.; Tonta, M.A.; Bourke, J.L.; Parkington, H.C.; Suzuki, H. Spontaneous electrical and $\mathrm{Ca}^{2+}$ signals in the mouse renal pelvis that drive pyeloureteric peristalsis. Clin. Exp. Pharmacol. Physiol. 2010, 37, 509-515. [CrossRef] [PubMed]

71. Drumm, B.T.; Koh, S.D.; Andersson, K.E.; Ward, S.M. Calcium signalling in cajal-like interstitial cells of the lower urinary tract. Nat. Rev. Urol. 2014, 11, 555-564. [CrossRef] [PubMed]

72. McCloskey, K.D.; Gurney, A.M. Kit positive cells in the guinea pig bladder. J. Urol. 2002, 168, 832-836. [CrossRef]

73. Hashitani, H.; Yanai, Y.; Suzuki, H. Role of interstitial cells and gap junctions in the transmission of spontaneous $\mathrm{Ca}^{2+}$ signals in detrusor smooth muscles of the guinea-pig urinary bladder. J. Physiol. 2004, 559, 567-581. [CrossRef] [PubMed]

74. Sergeant, G.P.; Hollywood, M.A.; McHale, N.G.; Thornbury, K.D. Ca ${ }^{2+}$ signalling in urethral interstitial cells of cajal. J. Physiol. 2006, 576, 715-720. [CrossRef] [PubMed]

75. Lam, M.; Shigemasa, Y.; Exintaris, B.; Lang, R.J.; Hashitani, H. Spontaneous $\mathrm{Ca}^{2+}$ signaling of interstitial cells in the guinea pig prostate. J. Urol. 2011, 186, 2478-2486. [CrossRef] [PubMed]

76. Deng, J.; He, P.; Zhong, X.; Wang, Q.; Li, L.; Song, B. Identification of t-type calcium channels in the interstitial cells of cajal in rat bladder. Urology 2012, 80, e1381-e1387. [CrossRef] [PubMed]

77. Nivala, M.; Ko, C.Y.; Nivala, M.; Weiss, J.N.; Qu, Z. The emergence of subcellular pacemaker sites for calcium waves and oscillations. J. Physiol. 2013, 591, 5305-5320. [CrossRef] [PubMed]

78. Pappas, A.; Wellman, G.C. Setting the pace for gi motility: Ryanodine receptors and ip3 receptors within interstitial cells of cajal. Focus on "intracellular $\mathrm{Ca}^{2+}$ release from endoplasmic reticulum regulates slow wave currents and pacemaker activity of interstitial cells of cajal”. Am. J. Physiol. 2015, 308, C606-C607. [CrossRef] [PubMed]

79. Singh, R.D.; Gibbons, S.J.; Saravanaperumal, S.A.; Du, P.; Hennig, G.W.; Eisenman, S.T.; Mazzone, A.; Hayashi, Y.; Cao, C.; Stoltz, G.J.; et al. Ano1, a Ca ${ }^{2+}$-activated Cl-channel, coordinates contractility in mouse intestine by $\mathrm{Ca}^{2+}$ transient coordination between interstitial cells of cajal. J. Physiol. 2014, 592, 4051-4068. [CrossRef] [PubMed]

80. Gong, Y.; Huang, L.; Cheng, W.; Li, X.; Lu, J.; Lin, L.; Si, X. Roles of interleukin-9 in the growth and cholecystokinin-induced intracellular calcium signaling of cultured interstitial cells of cajal. PLOS ONE 2014, 9, e95898. [CrossRef] [PubMed]

81. Ye, J.; Zhu, Y.; Khan, W.I.; Van Snick, J.; Huizinga, J.D. Il-9 enhances growth of icc, maintains network structure and strengthens rhythmicity of contraction in culture. J. Cell. Mol. Med. 2006, 10, 687-694. [CrossRef] [PubMed]

82. Wang, X.Y.; Zarate, N.; Soderholm, J.D.; Bourgeois, J.M.; Liu, L.W.; Huizinga, J.D. Ultrastructural injury to interstitial cells of cajal and communication with mast cells in crohn's disease. Neurogastroenterol. Motility 2007, 19, 349-364. [CrossRef] [PubMed]

83. Song, R.; Fullerton, D.A.; Ao, L.; Zheng, D.; Zhao, K.S.; Meng, X. Bmp-2 and TGF-beta1 mediate biglycan-induced pro-osteogenic reprogramming in aortic valve interstitial cells. J. Mol. Med. 2015, 93, 403-412. [CrossRef] [PubMed] 
84. Yu, Z.; Seya, K.; Daitoku, K.; Motomura, S.; Fukuda, I.; Furukawa, K. Tumor necrosis factor-alpha accelerates the calcification of human aortic valve interstitial cells obtained from patients with calcific aortic valve stenosis via the bmp2-dlx5 pathway. J. Pharmacol. Exp. Therap. 2011, 337, 16-23. [CrossRef] [PubMed]

85. Hafizi, S.; Taylor, P.M.; Chester, A.H.; Allen, S.P.; Yacoub, M.H. Mitogenic and secretory responses of human valve interstitial cells to vasoactive agents. J. Heart Valve Dis. 2000, 9, 454-458. [PubMed]

86. Choi, S.; Park, D.Y.; Yeum, C.H.; Chang, I.Y.; You, H.J.; Park, C.G.; Kim, M.Y.; Kong, I.D.; So, I.; Kim, K.W.; et al. Bradykinin modulates pacemaker currents through bradykinin b2 receptors in cultured interstitial cells of cajal from the murine small intestine. Br. J. Pharmacol. 2006, 148, 918-926. [CrossRef] [PubMed]

87. Kim, B.J.; Kwon, Y.K.; Kim, E.; So, I. Effects of histamine on cultured interstitial cells of cajal in murine small intestine. Korean J. Physiol. Pharmacol. 2013, 17, 149-156. [CrossRef] [PubMed]

88. Rumessen, J.J. Identification of interstitial cells of cajal. Significance for studies of human small intestine and colon. Dan. Med. Bull. 1994, 41, 275-293. [PubMed]

89. Park, K.J.; Hennig, G.W.; Lee, H.T.; Spencer, N.J.; Ward, S.M.; Smith, T.K.; Sanders, K.M. Spatial and temporal mapping of pacemaker activity in interstitial cells of cajal in mouse ileum in situ. Am. J. Physiol. 2006, 290, C1411-C1427. [CrossRef] [PubMed]

90. Wang, Z.Y.; Huang, X.; Liu, D.H.; Lu, H.L.; Kim, Y.C.; Xu, W.X. Involvement of actin microfilament in regulation of pacemaking activity increased by hypotonic stress in cultured iccs of murine intestine. Physiol. Res. 2015, 64, 397-405. [PubMed]

91. Torihashi, S.; Fujimoto, T.; Trost, C.; Nakayama, S. Calcium oscillation linked to pacemaking of interstitial cells of cajal: Requirement of calcium influx and localization of trp4 in caveolae. J. Biol. Chem. 2002, 277, 19191-19197. [CrossRef] [PubMed]

92. Chaudhury, A. Furthering the debate on the role of interstitial cells of cajal in enteric inhibitory neuromuscular neurotransmission. Am. J. Physiol. 2016, 311, C479-C481. [CrossRef] [PubMed]

93. McHale, N.G.; Hollywood, M.A.; Sergeant, G.P.; Shafei, M.; Thornbury, K.T.; Ward, S.M. Organization and function of icc in the urinary tract. J. Physiol. 2006, 576, 689-694. [CrossRef] [PubMed]

94. McCloskey, K.D. Interstitial cells of cajal in the urinary tract. Handbook Exp. Pharmacol. 2011, $233-254$.

95. Wu, C.; Sui, G.P.; Fry, C.H. Purinergic regulation of guinea pig suburothelial myofibroblasts. J. Physiol. 2004, 559, 231-243. [CrossRef] [PubMed]

96. Gray, S.M.; McGeown, J.G.; McMurray, G.; McCloskey, K.D. Functional innervation of guinea-pig bladder interstitial cells of cajal subtypes: Neurogenic stimulation evokes in situ calcium transients. PLoS ONE 2013, 8, e53423. [CrossRef] [PubMed]

97. Lang, R.J.; Zoltkowski, B.Z.; Hammer, J.M.; Meeker, W.F.; Wendt, I. Electrical characterization of interstitial cells of cajal-like cells and smooth muscle cells isolated from the mouse ureteropelvic junction. J. Urol. 2007, 177, 1573-1580. [CrossRef] [PubMed]

98. Fu, X.; Liu, Y.J.; Ciray, N.; Olovsson, M.; Ulmsten, U.; Gylfe, E. Oxytocin-induced oscillations of cytoplasmic $\mathrm{Ca}^{2+}$ in human myometrial cells. Acta Obstet. Gynecol Scand. 2000, 79, 174-179. [CrossRef] [PubMed]

99. Young, R.C.; Zhang, P. The mechanism of propagation of intracellular calcium waves in cultured human uterine myocytes. Am. J. Obstet. Gynecol. 2001, 184, 1228-1234. [CrossRef] [PubMed]

100. Loftus, F.C.; Richardson, M.J.; Shmygol, A. Single-cell mechanics and calcium signalling in organotypic slices of human myometrium. J. Biomech. 2015, 48, 1620-1624. [CrossRef] [PubMed]

101. Dixon, R.E.; Ramsey, K.H.; Schripsema, J.H.; Sanders, K.M.; Ward, S.M. Time-dependent disruption of oviduct pacemaker cells by chlamydia infection in mice. Biol. Reproduct. 2010, 83, 244-253. [CrossRef] [PubMed]

102. Matzkin, M.E.; Lauf, S.; Spinnler, K.; Rossi, S.P.; Kohn, F.M.; Kunz, L.; Calandra, R.S.; Frungieri, M.B.; Mayerhofer, A. The $\mathrm{Ca}^{2+}$-activated, large conductance $\mathrm{K}^{+}$-channel (bkca) is a player in the $\mathrm{lh} / \mathrm{hcg}$ signaling cascade in testicular leydig cells. Mol. Cell. Endocrinol. 2013, 367, 41-49. [CrossRef] [PubMed]

103. Costa, R.R.; Reis, R.I.; Aguiar, J.F.; Varanda, W.A. Luteinizing hormone (lh) acts through pka and pkc to modulate t-type calcium currents and intracellular calcium transients in mice leydig cells. Cell Calcium 2011, 49, 191-199. [CrossRef] [PubMed]

104. Lee, J.H.; Kim, J.U.; Kim, C.; Min, C.K. Inhibitory actions of mibefradil on steroidogenesis in mouse leydig cells: Involvement of $\mathrm{Ca}(2+)$ entry via the t-type $\mathrm{Ca}(2+)$ channel. Asian J. Androl. 2010, 12, 807-813. [CrossRef] [PubMed] 
105. Pardyak, L.; Kaminska, A.; Galas, J.; Ptak, A.; Bilinska, B.; Kotula-Balak, M. Primary and tumor mouse leydig cells exposed to polychlorinated naphthalenes mixture: Effect on estrogen related-receptors expression, intracellular calcium level and sex hormones secretion. Tissue Cell 2016, 48, 432-441. [CrossRef] [PubMed]

106. Abdou, H.S.; Villeneuve, G.; Tremblay, J.J. The calcium signaling pathway regulates leydig cell steroidogenesis through a transcriptional cascade involving the nuclear receptor nr4a1 and the steroidogenic acute regulatory protein. Endocrinology 2013, 154, 511-520. [CrossRef] [PubMed]

107. Abdou, H.S.; Robert, N.M.; Tremblay, J.J. Calcium-dependent nr4a1 expression in mouse leydig cells requires distinct ap1/cre and mef2 elements. J. Mol. Endocrinol. 2016, 56, 151-161. [CrossRef] [PubMed]

108. Harhun, M.I. Mitochondrial $\mathrm{Ca}^{2+}$ handling is crucial for generation of rhythmical $\mathrm{Ca}^{2+}$ waves in vascular interstitial cells from rabbit portal vein. Cell Calcium 2015, 58, 325-329. [CrossRef] [PubMed]

109. Harhun, M.I.; Gordienko, D.V.; Povstyan, O.V.; Moss, R.F.; Bolton, T.B. Function of interstitial cells of cajal in the rabbit portal vein. Circ. Res. 2004, 95, 619-626. [CrossRef] [PubMed]

110. Harhun, M.; Gordienko, D.; Kryshtal, D.; Pucovsky, V.; Bolton, T. Role of intracellular stores in the regulation of rhythmical $\left[\mathrm{Ca}^{2+}\right] \mathrm{i}$ changes in interstitial cells of cajal from rabbit portal vein. Cell Calcium 2006, 40, 287-298. [CrossRef] [PubMed]

111. Bolton, T.B.; Gordienko, D.V.; Povstyan, O.V.; Harhun, M.I.; Pucovsky, V. Smooth muscle cells and interstitial cells of blood vessels. Cell Calcium 2004, 35, 643-657. [CrossRef] [PubMed]

112. Pucovsky, V.; Bolton, T.B. Localisation, function and composition of primary $\mathrm{Ca}^{2+}$ spark discharge region in isolated smooth muscle cells from guinea-pig mesenteric arteries. Cell Calcium 2006, 39, 113-129. [CrossRef] [PubMed]

113. Harhun, M.I.; Pucovsky, V.; Povstyan, O.V.; Gordienko, D.V.; Bolton, T.B. Interstitial cells in the vasculature. J. Cell. Mol. Med. 2005, 9, 232-243. [CrossRef] [PubMed]

114. Harhun, M.I.; Szewczyk, K.; Laux, H.; Prestwich, S.A.; Gordienko, D.V.; Moss, R.F.; Bolton, T.B. Interstitial cells from rat middle cerebral artery belong to smooth muscle cell type. J. Cell. Mol. Med. 2009, 13, 4532-4539. [CrossRef] [PubMed]

115. Huggins, C.L.; Povstyan, O.V.; Harhun, M.I. Characterization of transcriptional and posttranscriptional properties of native and cultured phenotypically modulated vascular smooth muscle cells. Cell Tissue Res. 2013, 352, 265-275. [CrossRef] [PubMed]

116. Harhun, M.I.; Huggins, C.L.; Ratnasingham, K.; Raje, D.; Moss, R.F.; Szewczyk, K.; Vasilikostas, G.; Greenwood, I.A.; Khong, T.K.; Wan, A.; et al. Resident phenotypically modulated vascular smooth muscle cells in healthy human arteries. J. Cell. Mol. Med. 2012, 16, 2802-2812. [CrossRef] [PubMed]

117. Gordienko, D.V.; Greenwood, I.A.; Bolton, T.B. Direct visualization of sarcoplasmic reticulum regions discharging $\mathrm{Ca}(2+)$ sparks in vascular myocytes. Cell Calcium 2001, 29, 13-28. [CrossRef] [PubMed]

118. Sun, W.; Zhao, R.; Yang, Y.; Wang, H.; Shao, Y.; Kong, X. Comparative study of human aortic and mitral valve interstitial cell gene expression and cellular function. Genomics 2013, 101, 326-335. [CrossRef] [PubMed]

119. Rabkin-Aikawa, E.; Farber, M.; Aikawa, M.; Schoen, F.J. Dynamic and reversible changes of interstitial cell phenotype during remodeling of cardiac valves. J. Heart Valve Dis. 2004, 13, 841-847. [PubMed]

120. Masjedi, S.; Amarnath, A.; Baily, K.M.; Ferdous, Z. Comparison of calcification potential of valvular interstitial cells isolated from individual aortic valve cusps. Cardiovasc. Pathol. 2016, 25, 185-194. [CrossRef] [PubMed]

121. Huizinga, J.D.; Thuneberg, L.; Kluppel, M.; Malysz, J.; Mikkelsen, H.B.; Bernstein, A. W/kit gene required for interstitial cells of cajal and for intestinal pacemaker activity. Nature 1995, 373, 347-349. [CrossRef] [PubMed]

122. Cretoiu, S.M.; Cretoiu, D.; Marin, A.; Radu, B.M.; Popescu, L.M. Telocytes: Ultrastructural, immunohistochemical and electrophysiological characteristics in human myometrium. Reproduction 2013, 145, 357-370. [CrossRef] [PubMed]

123. Campeanu, R.A.; Radu, B.M.; Cretoiu, S.M.; Banciu, D.D.; Banciu, A.; Cretoiu, D.; Popescu, L.M. Near-infrared low-level laser stimulation of telocytes from human myometrium. Lasers Med. Sci. 2014, 29, 1867-1874. [CrossRef] [PubMed]

124. Sheng, J.; Shim, W.; Lu, J.; Lim, S.Y.; Ong, B.H.; Lim, T.S.; Liew, R.; Chua, Y.L.; Wong, P. Electrophysiology of human cardiac atrial and ventricular telocytes. J. Cell. Mol. Med. 2014, 18, 355-362. [CrossRef] [PubMed]

125. Deng, X.S.; Meng, X.; Song, R.; Fullerton, D.; Jaggers, J. Rapamycin decreases the osteogenic response in aortic valve interstitial cells through the stat3 pathway. Ann. Thoracic Surg. 2016, 102, 1229-1238. [CrossRef] [PubMed] 
126. Helas, S.; Goettsch, C.; Schoppet, M.; Zeitz, U.; Hempel, U.; Morawietz, H.; Kostenuik, P.J.; Erben, R.G.; Hofbauer, L.C. Inhibition of receptor activator of NF- $k B$ ligand by denosumab attenuates vascular calcium deposition in mice. Am. J. Pathol. 2009, 175, 473-478. [CrossRef] [PubMed]

127. Lerman, D.A.; Prasad, S.; Alotti, N. Denosumab could be a potential inhibitor of valvular interstitial cells calcification in vitro. Int. J. Cardiovasc. Res. 2016, 5. [CrossRef] [PubMed]

128. Der, T.; Bercik, P.; Donnelly, G.; Jackson, T.; Berezin, I.; Collins, S.M.; Huizinga, J.D. Interstitial cells of cajal and inflammation-induced motor dysfunction in the mouse small intestine. Gastroenterology 2000, 119, 1590-1599. [CrossRef] [PubMed]

129. Kaji, N.; Horiguchi, K.; Iino, S.; Nakayama, S.; Ohwada, T.; Otani, Y.; Firman; Murata, T.; Sanders, K.M.; Ozaki, H.; et al. Nitric oxide-induced oxidative stress impairs pacemaker function of murine interstitial cells of cajal during inflammation. Pharmacol. Res. 2016, 111, 838-848. [CrossRef] [PubMed]

130. Cretoiu, D.; Cretoiu, S.M. Telocytes in the reproductive organs: Current understanding and future challenges. Semin. Cell Dev. Biol. 2016. [CrossRef] [PubMed]

131. Peri, L.E.; Koh, B.H.; Ward, G.K.; Bayguinov, Y.; Hwang, S.J.; Gould, T.W.; Mullan, C.J.; Sanders, K.M.; Ward, S.M. A novel class of interstitial cells in the mouse and monkey female reproductive tracts. Biol. Reproduct. 2015, 92, 102. [CrossRef] [PubMed]

132. Kashyap, P.; Gomez-Pinilla, P.J.; Pozo, M.J.; Cima, R.R.; Dozois, E.J.; Larson, D.W.; Ordog, T.; Gibbons, S.J.; Farrugia, G. Immunoreactivity for ano1 detects depletion of kit-positive interstitial cells of cajal in patients with slow transit constipation. Neurogastroenterol. Motil. 2011, 23, 760-765. [CrossRef] [PubMed]

133. Zhou, Q.; Wei, L.; Zhong, C.; Fu, S.; Bei, Y.; Huica, R.I.; Wang, F.; Xiao, J. Cardiac telocytes are double positive for cd34/pdgfr-alpha. J. Cell. Mol. Med. 2015, 19, 2036-2042. [CrossRef] [PubMed]

134. Li, Y.Y.; Zhang, S.; Li, Y.G.; Wang, Y. Isolation, culture, purification and ultrastructural investigation of cardiac telocytes. Mol. Med. Rep. 2016, 14, 1194-1200. [CrossRef] [PubMed]

135. Shynlova, O.; Tsui, P.; Jaffer, S.; Lye, S.J. Integration of endocrine and mechanical signals in the regulation of myometrial functions during pregnancy and labour. Eur. J. Obs. Gynecol. Reproduct. Biol. 2009, 144, S2-S10. [CrossRef] [PubMed]

136. Roatesi, I.; Radu, B.M.; Cretoiu, D.; Cretoiu, S.M. Uterine telocytes: A review of current knowledge. Biol. Reproduct. 2015, 93, 10. [CrossRef] [PubMed]

137. Rosenbaum, S.T.; Svalo, J.; Nielsen, K.; Larsen, T.; Jorgensen, J.C.; Bouchelouche, P. Immunolocalization and expression of small-conductance calcium-activated potassium channels in human myometrium. J. Cell. Mol. Med. 2012, 16, 3001-3008. [CrossRef] [PubMed]

138. Rosenbaum, S.T.; Larsen, T.; Joergensen, J.C.; Bouchelouche, P.N. Relaxant effect of a novel calcium-activated potassium channel modulator on human myometrial spontaneous contractility in vitro. Acta Physiol. 2012, 205, 247-254. [CrossRef] [PubMed]

139. Chang, Y.; Li, C.; Lu, Z.; Li, H.; Guo, Z. Multiple immunophenotypes of cardiac telocytes. Exp. Cell Res. 2015, 338, 239-244. [CrossRef] [PubMed]

140. Bei, Y.; Zhou, Q.; Fu, S.; Lv, D.; Chen, P.; Chen, Y.; Wang, F.; Xiao, J. Cardiac telocytes and fibroblasts in primary culture: Different morphologies and immunophenotypes. PLoS ONE 2015, 10, e0115991. [CrossRef] [PubMed]

141. Lai, M.H.; Wu, Y.; Gao, Z.; Anderson, M.E.; Dalziel, J.E.; Meredith, A.L. Bk channels regulate sinoatrial node firing rate and cardiac pacing in vivo. Am. J. Physiol. 2014, 307, H1327-H1338. [CrossRef] [PubMed]

142. Chi, C.; Jiang, X.J.; Su, L.; Shen, Z.J.; Yang, X.J. In vitro morphology, viability and cytokine secretion of uterine telocyte-activated mouse peritoneal macrophages. J. Cell. Mol. Med. 2015, 19, 2741-2750. [CrossRef] [PubMed]

143. Manole, C.G.; Gherghiceanu, M.; Simionescu, O. Telocyte dynamics in psoriasis. J. Cell. Mol. Med. 2015, 19, 1504-1519. [CrossRef] [PubMed]

144. Karvonen, S.L.; Korkiamaki, T.; Yla-Outinen, H.; Nissinen, M.; Teerikangas, H.; Pummi, K.; Karvonen, J.; Peltonen, J. Psoriasis and altered calcium metabolism: Downregulated capacitative calcium influx and defective calcium-mediated cell signaling in cultured psoriatic keratinocytes. J. Investig. Dermatol. 2000, 114, 693-700. [CrossRef] [PubMed]

145. Steinckwich, N.; Myers, P.; Janardhan, K.S.; Flagler, N.D.; King, D.; Petranka, J.G.; Putney, J.W. Role of the store-operated calcium entry protein, stim1, in neutrophil chemotaxis and infiltration into a murine model of psoriasis-inflamed skin. FASEB J. 2015, 29, 3003-3013. [CrossRef] [PubMed] 
146. Staniak, H.L.; Bittencourt, M.S.; de Souza Santos, I.; Sharovsky, R.; Sabbag, C.; Goulart, A.C.; Lotufo, P.A.; Bensenor, I.M. Association between psoriasis and coronary calcium score. Atherosclerosis 2014, 237, 847-852. [CrossRef] [PubMed]

147. Qadim, H.H.; Goforoushan, F.; Nejad, S.B.; Goldust, M. Studying the calcium serum level in patients suffering from psoriasis. Pak. J. Biol. Sci. 2013, 16, 291-294. [PubMed]

148. Cairns, R.A.; Harris, I.S.; Mak, T.W. Regulation of cancer cell metabolism. Nat. Rev. Cancer 2011, 11, 85-95. [CrossRef] [PubMed]

149. Kreymann, G.; Grosser, S.; Buggisch, P.; Gottschall, C.; Matthaei, S.; Greten, H. Oxygen consumption and resting metabolic rate in sepsis, sepsis syndrome, and septic shock. Crit. Care Med. 1993, 21, 1012-1019. [CrossRef] [PubMed]

150. Weibel, E.R.; Bacigalupe, L.D.; Schmitt, B.; Hoppeler, H. Allometric scaling of maximal metabolic rate in mammals: Muscle aerobic capacity as determinant factor. Respir. Physiol. Neurobiol. 2004, 140, 115-132. [CrossRef] [PubMed]

151. Valiani, V.; Corbett, D.B.; Knaggs, J.D.; Manini, T.M. Metabolic rate and perceived exertion of walking in older adults with idiopathic chronic fatigue. J. Gerontol. A 2016, 71, 1444-1450. [CrossRef] [PubMed]

152. Kota, S.K.; Gayatri, K.; Jammula, S.; Kota, S.K.; Krishna, S.V.; Meher, L.K.; Modi, K.D. Endocrinology of parturition. Ind. J. Endocrinol. Metab. 2013, 17, 50-59. [CrossRef] [PubMed]

153. Yamamoto, Y.; Oguri, H.; Yamada, R.; Maeda, N.; Kohsaki, S.; Fukaya, T. Preoperative evaluation of pelvic masses with combined 18f-fluorodeoxyglucose positron emission tomography and computed tomography. Int. J. Gynaecol. Obstet. 2008, 102, 124-127. [CrossRef] [PubMed]

154. Nilsson, U.K.; Svensson, S.P. Inhibition of $\mathrm{Ca}^{2+} /$ calmodulin-dependent protein kinase or epidermal growth factor receptor tyrosine kinase abolishes lysophosphatidic acid-mediated DNA-synthesis in human myometrial smooth muscle cells. Cell Biol. Int. 2003, 27, 341-347. [CrossRef]

155. Wimalasundera, R.C.; Thom, S.A.; Regan, L.; Hughes, A.D. Effects of vasoactive agents on intracellular calcium and force in myometrial and subcutaneous resistance arteries isolated from preeclamptic, pregnant, and nonpregnant woman. Am. J. Obstet. Gynecol. 2005, 192, 625-632. [CrossRef] [PubMed]

156. Chistiakov, D.A.; Orekhov, A.N.; Bobryshev, Y.V. The role of cardiac fibroblasts in post-myocardial heart tissue repair. Exp. Mol. Pathol. 2016, 101, 231-240. [CrossRef] [PubMed]

157. Popescu, L.M.; Gherghiceanu, M.; Hinescu, M.E.; Cretoiu, D.; Ceafalan, L.; Regalia, T.; Popescu, A.C.; Ardeleanu, C.; Mandache, E. Insights into the interstitium of ventricular myocardium: Interstitial cajal-like cells (ICLC). J. Cell. Mol. Med. 2006, 10, 429-458. [CrossRef] [PubMed] 